Florida International University FIU Digital Commons

$6-27-2013$

\title{
Foreign-born CEOs, Country-Specific Skills, Selection, and Strategic Consequences
}

Yannick Thams

Florida International University, ytham001@fiu.edu

DOI: $10.25148 /$ etd.FI13080905

Follow this and additional works at: https:// digitalcommons.fiu.edu/etd

Part of the International Business Commons, and the Strategic Management Policy Commons

\section{Recommended Citation}

Thams, Yannick, "Foreign-born CEOs, Country-Specific Skills, Selection, and Strategic Consequences" (2013). FIU Electronic Theses and Dissertations. 934.

https://digitalcommons.fiu.edu/etd/934

This work is brought to you for free and open access by the University Graduate School at FIU Digital Commons. It has been accepted for inclusion in FIU Electronic Theses and Dissertations by an authorized administrator of FIU Digital Commons. For more information, please contact dcc@fiu.edu. 


\title{
FLORIDA INTERNATIONAL UNIVERSITY \\ Miami, Florida
}

\section{FOREIGN-BORN CEOS, COUNTRY-SPECIFIC SKILLS, SELECTION, AND STRATEGIC CONSEQUENCES}

\author{
A dissertation submitted in partial fulfillment of the \\ requirements for the degree of \\ DOCTOR OF PHILOSOPHY \\ in \\ BUSINESS ADMINISTRATION \\ by \\ Yannick Thams
}

2013 
To: Dean David Klock

College of Business Administration

This dissertation, written by Yannick Thams, and entitled Foreign-born CEOs, CountrySpecific Skills, Selection, and Strategic Consequences, having been approved in respect to style and intellectual content, is referred to you for judgment.

We have read this dissertation and recommend that it be approved.

$\begin{array}{r}\hline \text { Joyce Elam } \\ \hline \text { William Newburry } \\ \hline \text { Mary Ann Von Glinow } \\ \hline \text { Margarethe Wiersema } \\ \hline \text { Aya Chacar, Major Professor }\end{array}$

Date of Defense: June 27, 2013

The dissertation of Yannick Thams is approved.

Dean Dean David Klock

College of Business Administration

Dean Lakshmi N. Reddi

University Graduate School

Florida International University, 2013 
C Copyright 2013 by Yannick Thams

All rights reserved. 


\section{DEDICATION}

I dedicate this dissertation to my parents and siblings. Without their moral support, patience, encouragement, their tremendous sacrifice, and above all their love, the completion of this work would not have been possible. Thank you for always being there for me and for believing in me. 


\section{ACKNOWLEDGEMENTS}

I wish to thank the members of my committee for their support, words of encouragement, and for sharing their knowledge. This work would not have been possible without the great devotion, dedication, patience, and feedback of Dr. Aya Chacar, the chair of my committee. Her guidance and her time commitment have been instrumental to the completion of this dissertation. She is a very developmental advisor and one who is willing to spend countless number of hours to teach her doctoral students. I am very grateful to her for having been there every step of this journey. I also would like to thank all the professors of the management doctoral program who have been very supportive.

I would like to acknowledge the financial support received from the FIU graduate school. 


\section{ABSTRACT OF THE DISSERTATION \\ FOREIGN-BORN CEOS, COUNTRY-SPECIFIC SKILLS, SELECTION, AND STRATEGIC CONSEQUENCES}

by

Yannick Thams

Florida International University, 2013

Miami, FL

Professor Aya Chacar, Major Professor

In this dissertation, I first suggest an extension of the managerial rents model and more specifically the managerial skills typology that it offers. Building on research in international business, I propose adding country-specific skills (CSS) to this typology in addition to firm-specific, industry-specific, and generic skills. I define CSS as managers' abilities that are applicable and specific to a particular national institutional context. Such skills are distinct from the other three types identified and are likely to influence managers' performance and the performance of their firms.

So if CSS are distinct skills, what are the implications for strategy and international business research? In an attempt to respond to this question, I conduct two empirical essays in which I examine the implications of this refinement of the typology of managerial skills for CEO selection and firms' mergers and acquisitions (M\&A) strategy.

In the first empirical essay, I puzzle at the fact that although CSS constitute a barrier to high-level executive mobility across countries, there have been a growing number of foreign-born CEOs being appointed across the globe. Why are these individuals being selected for the post of CEO? Using information on the appointment of 
foreign-born and national CEOs from 2005 to 2010 among global 500 companies, I show that internationalization pressures help explain their selection and that two types of firms are likely to appoint foreign leaders: highly internationalized firms and firms that are likely to internationalize.

In the second empirical essay, I examine the strategic implications of countryspecific skills. Employing the same sample as the one used in the first empirical essay, I demonstrate that given that their mindset is likely to be less focused on firms' home market, foreign-born CEOs may be prone to institute more changes in firms' cross-border M\&A strategy than their domestic counterparts. I also theorize on the moderating influence of CEOs' insiderness. 


\section{TABLE OF CONTENTS}

CHAPTER

PAGE

I. Extending The Managerial Rents Model: The Role of Country-Specific Skills..........1

Abstract.............................................................

Introduction...........................................................

Managerial Rent Model Review.............................................. 5

Extension of Managerial Skills Typology ................................... 10

Implications of Country-Specific Skills ................................... 13

Discussion and Conclusion................................................ 18

References.......................................................... 20

II. Firms' Current and Future Strategic Needs and Foreign-Born CEO

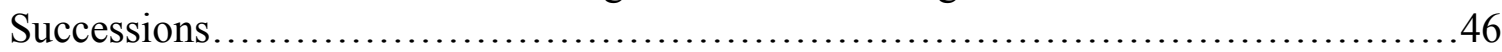

Abstract...........................................................46

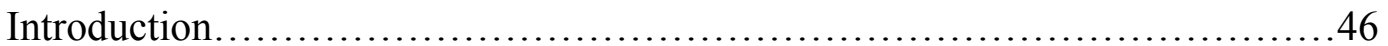

Organizational Antecedents to CEO Successions...............................50

Non-National Versus National CEO Successions...........................54

Methods..........................................................65

Results............................................................... 69

Discussion and Conclusion................................................ 74

References........................................................ 78

III. Foreign-Born CEO Successions and Changes in M\&A

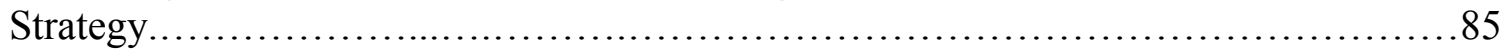

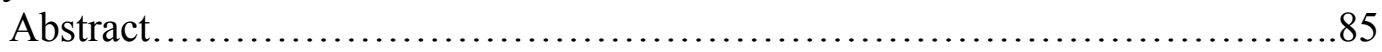

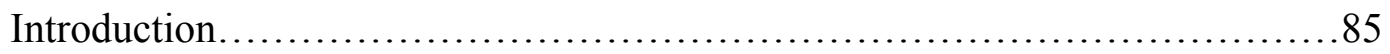

Types of Successions and their Strategic Impact............................. 89

Hypotheses Development............................................... 93

Methods.............................................................. 100

Results............................................................... 105

Discussion and Conclusion............................................... 88

References..................................................... 92

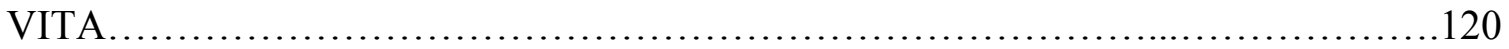




\section{LIST OF TABLES}

TABLE

PAGE

1. Matching CEO skills to Firm's Current and Changing Needs......................51

2. Successions Characteristics per Year......................................66

3. Summary Statistics and Zero-Order Correlation Coefficients......................71

4. Drivers of Foreign-Born CEO Appointments..................................72

5. Summary Statistics and Zero-Order Correlation Coefficients.............................107

6. Drivers of Changes in Cross-Border M\&As.................................. 108

7. Drivers of Changes in Domestic M\&As.......................................... 109 


\title{
Extending The Managerial Rents Model: The Role of Country-Specific Skills
}

\begin{abstract}
This study extends the managerial skills typology of the managerial rents model. I specifically propose adding country-specific skills in addition to firm-specific, industryspecific, and generic skills. Country-specific skills refer to managers' abilities and knowledge that are applicable and specific to a particular national institutional context. These skills are valuable, rare, hard to imitate, and substitute. They are also distinct from the other three types identified. I argue that ultimately their heterogeneity matter in many arenas expanding on their impact for managerial selection, managerial actions, and ultimately firm performance.
\end{abstract}

\section{INTRODUCTION}

Castanias and Helfat (1991) developed the managerial rents model that was fleshed out and refined over the years (e.g., Bailey \& Helfat, 2001; Castanias \& Helfat, 2001; Holcomb, Holmes, \& Conelly, 2009). Drawing on human capital theory, this model reiterated the importance of managerial resources as important components of the entire bundle of firm resources. It argued that managerial resources defined as skills and abilities of managers are neither uniform nor homogeneous across firms and can generate both Ricardian rent, due to rarity, and quasi-rent, due to co-specialization with the firm.

Another key contribution of this model is the managerial skills typology that it provides. Contrary to previous typologies of managerial skills (e.g., Becker, 1962; Katz, 
1974; Steiner, Miner, \& Gray, 1986) that ignored the external context in which managers skills are employed, Castanias and Helfat (1991) took into account managers' organizational and environmental settings. They developed a typology of managerial skills composed of not only generic skills but also firm-specific skills and industryspecific skills. This study proposes two interrelated extensions to this model by drawing on insights from international business (IB) research and institutional theory (Crossland \& Hambrick, 2007; 2011; North, 1990; 1991; Witt \& Redding, 2009).

The first extension relates to expanding the typology of managerial skills to factor in the broader institutional context in which managerial skills are employed. Indeed, Castanias and Helfat (1991) argued that skills need to be considered in the environment in which they are used and their importance reevaluated as the environment changes. With industry globalization changing the environment in which firms operate and geographic diversification altering firms' competitive landscape (Wiersema \& Bowen, 2008 ; 2011), another category of skills that is coming to the fore is the ability to manage effectively within a national institutional environment or what I call country-specific skills (CSS). Indeed, the national institutional environments in which firms are embedded can alter their performance (Chacar \& Vissa, 2005; Chacar, Newburry, \& Vissa, 2010). Moreover, national institutional environments shape managerial roles and skills (Crossland \& Hambrick, 2007).

I specifically argue that as managers develop firm-specific and industry-specific skills being infused in a particular company or industry context (Castanias \& Helfat, 1991), they are also likely to build skills and knowledge that are idiosyncratic to a particular national institutional environment. I define country-specific skills as the 
abilities of managers that are developed through experience in a particular national institutional context. Country-specific skills are valuable, rare, hard to imitate, and to substitute (Barney, 1991). They are also distinct from the other three types identified and will influence managers' performance and the performance of their firms. Clearly, some of the institutionally-related skills may fall under generic skills and are not categorized under CSS. But just as managing in certain product markets or industries may require specialized skills (Castanias \& Helfat, 1991) compared to generic managerial skills, managing in certain national environments requires idiosyncratic skills and knowledge applicable to a particular national institutional environment. Managers also often internalize the norms and management philosophy/ideology prevailing in their home nations, which then become taken-for-granted (Porter, 1990). As such, managerial skills, values, and ultimately actions may differ across institutional contexts.

The second extension relates to the formation of managerial skills. While the managerial rents model focuses mainly on skills and abilities acquired primarily through managerial experience or by exercising the managerial duty (Castanias \& Helfat, 1991; Harris \& Helfat, 1997), I propose that managers are also likely to develop institutionallyrelated skills and CSS through personal experiences. Growing up and spending their formative years in a particular country might help individuals develop cultural patterns and other institutionally-related knowledge that could help managers exercise their managerial duty (Nielsen \& Nielsen, 2013). For example, being born and growing up in Japan might help an individual develop cultural patterns centered on long-term orientation. This long-term orientation might affect this person's ability to engage in quick decision-making (Crossland \& Hambrick, 2007), a skill that may be indispensable 
to manage in other institutional settings such as the United States where managers are often evaluated on their firms' quarterly results.

Considering the heterogeneity of CSS, it is important to study them and their implications. I further explore the implications of country-specific skills for managerial mobility and selection, firm performance, and managerial compensation. I first argue that geographical diversification will bring to light the necessity to consider CSS in the executive selection process. Second, I postulate that if CSS are rare, valuable, and hard to imitate, they have the potential to generate a competitive advantage for firms considering them as a managerial resource; such competitive advantage may in turn have a positive impact of firm performance. In parallel, managers holding these superior skills may be able to generate superior rent for the firm and for themselves in the form of higher compensation.

In the following, I first review the managerial rents model and some of the work it has inspired. I then make a case to add country-specific skills as an additional set of skills that are crucial to consider with our increasingly global world. Finally, I draw some implications and extensions for extant theory and discuss the implications of this study and potential future research.

Exploring this research commands attention as it offers an important extension to the managerial skills typology developed by Castanias \& Helfat (1991). It also complements current IB research on the role of institutional contexts in shaping economic behaviors (North, 1991), by tying these contexts to the development of managerial skills. 


\section{MANAGERIAL RENTS MODEL REVIEW}

The importance of managers and human assets to firms has been the object of interest of researchers from Taylor's work on time and motion studies (e.g., Adler, 1993) to the present (e.g., Holcomb et al., 2009; Ployhart, Van Iddekinge, \& Mackenzie, 2011; Wang \& Barney, 2006). Microeconomic writing on the other hand often assumed away the importance of managers by considering managerial skills as homogeneous and hence irrelevant for study, and by describing the firm in terms of a production function (Marshall, 1890). Speaking to these economists, Castanias and Helfat (1991) offered the managerial rents model whose fundamental proposition is that 'managers differ in the type and quality of their skills' (2001: 662).

While this proposition may seem obvious to most management theorists, it was a an important contribution considering its background setting of neoclassical economic thinking and models of firms assuming managerial homogeneity within and across firms. Even within management theory, many scholars have examined whether top managers and chief executive officers (CEOs) in specific, created value to the firm (Finkelstein, Hambrick, \& Canella, 2009; Lieberson \& O’ Connor, 1972; Mackey, 2008; Thomas, 1988). Drawing on population ecology, other researchers also doubted the ability of top managers to influence firm performance since top leaders may be highly constrained by numerous inertial forces existing within large organizations and by their environment (Finkelstein et al., 2009; Hannan \& Freeman, 1977; 1984; Wasserman, Nohria, \& Anand, 2001).

Within this background, Castanias and Helfat and colleagues proposed, in a nutshell, that not only managerial skills are heterogeneous, but that they are also likely to 
be valuable, rare, and imperfectly imitable and substitutable and hence have the potential to generate rent to the firm, alone or in combination with other firm resources (Bailey \& Helfat, 2001; Barney, 1991; Castanias \& Helfat, 1991; 2001; Harris \& Helfat, 1997). In this model, managers can earn both Ricardian rent, due to rarity, and quasi-rent, due to co-specialization with the firm. Most importantly, Castanias and Helfat and colleagues argue that ultimately payment for skills, as well as the possibility of getting part of the quasi-rent generated aligns managers' interests to those of shareholders.

While this model has been extremely valuable and has a number of layers of interest, I focus here on the typology of managerial skills that it offers. I review this typology below and argue that it now needs to be broadened to take into consideration the institutional environment of the firm.

\section{Typology and Environment}

The typology of managerial skills proposed by the authors was fleshed out as their thinking progressed on the matter. In their original work, Castanias and Helfat (1991: 160) discussed three types of skills. First, generic skills refer to skills that are transferable across industries, businesses, and firms. They could include general abilities such as conceptual, leadership, and communication skills among many others (Katz, 1964; Steiner et al., 1986; Yukl, 1981). General skills have also been described by economists as skills acquired through formal education such as abilities developed when pursuing a MBA (Finegold, Benson, \& Mohrman, 2002; Murphy \& Zábojník, 2004; Ployhart et al., 2011). In addition, evidence from case-based research suggests that some executives' general abilities such as "setting a vision, motivating employees, organizing, budgeting, 
and monitoring performance" can be easily transferrable across firms and environments (Groysberg, McLean, \& Norhia 2006, p. 1).

The second type of skills alludes to industry-related skills or the "technical, regulatory, customer, or supplier knowledge unique to an industry" (Groysberg et al., 2006, p. 3). The idea is that executives need to have enough industry background to manage effectively (Castanias \& Helfat, 1991). For example, a CEO leading a firm operating under the rules of the U.S. Food and Drug Administration develop different industry-specific skills vis-à-vis his/her counterpart managing a firm having to comply with the requirements of the Federal Energy Regulatory Commission (Groysberg et al., 2006). Similarly, managing an electric power company involves regulatory and technological knowledge that is vital to the production and delivery of electric energy. However, such skills may not be valued by firms providing other types of services (Neil, 1995).

The third category of managerial skills includes firm-specific skills. Firm-specific skills have an immense value for organizations. Castanias and Helfat (1991) maintain that "the ability to effectively manage an organization may require in-depth understanding of the company's history, culture, internal strengths and weaknesses, etc...” (159). Firmspecific skills could also be defined as "knowledge of how a firm operates, knowledge about a firm's key suppliers and customers, and knowledge about how to work effectively with other employees" (Wang \& Barney, 2006, p. 466). If we take the example of a surgeon, his/her work depends to a great extent on his/her ability to work effectively with other hospital's employees. It is therefore imperative for surgeons to develop knowledge about how to successfully communicate with nurses, anesthetists, and 
other surgeons of the particular hospital in which they work (Groysberg, Sant, \& Abrahams, 2008).

Bailey and Helfat (2001) then revised and streamlined this typology to include four categories of skills that are also used in a follow-up article written by Castanias and Helfat (2001). The authors argued that there are four rather than three types of hierarchical managerial skills starting with the most specialized or 'firm-specific skills,' a category identical in both the earlier and later classification provided by the authors. The second and third classifications are a refinement of the prior 'business or industry related skills' now separated into industry-specific skills and related-industry skills. The fourth and final category is generic skills previously defined as "those that are transferable across industries, businesses, and firms" (Castanias \& Helfat, 1991, p. 160).

These skills could be conceptualized as a nested hierarchy of managerial human capital with different echelons of skills (Castanias \& Helfat, 2001). The hierarchy is formed based on the degree of specificity of the skill to the company in which the individual works (Harris \& Helfat, 1997). Skills also vary according to their degree of transferability and portability (Becker, 1964; Castanias \& Helfat, 1991; Groysberg et al., 2008). When executives move from a firm to another one within the same industry, their previous company's skills devaluate while their industry-specific knowledge could still be highly valuable (Harris \& Helfat, 1997). These skills can even become more valuable considering they could include knowledge of a competitor's operation (Finkelstein et al., 2009).

Excluding the latter, firm-specific skills are the least mobile skills since they are only applicable to the firm's context as opposed to generic skills that can generate value 
for any firms using them (Holcomb et al., 2009). Extant research shows that such degree of transferability and portability has important implications for managerial compensation (e.g., Carpenter, Sanders, \& Gregersen, 2001; Combs \& Skill, 2003; Finkelstein et al., 2009; Graham, Li, \& Qiu, 2012; Harris \& Helfat, 1997; Murphy \& Zábojník, 2004). For instance, in a study contrasting the initial compensation of internal CEO successors and external successors, Harris and Helfat (1997) found that external successors might obtain a pay premium vis-à-vis their insider counterparts partly due to the increased risk of failure associated with their lack of firm-specific skills in their new company and the low degree of transferability of their existing firm-specific skills.

According to Castanias and Helfat (2001), human capital and skills are identical concepts and relate to "innate and learned abilities, expertise, and knowledge" (662). While the authors acknowledge that managers can develop skills through different mechanisms and that skills could be influenced by managers' innate abilities and personality characteristics, the mechanisms on which they focus is prior work experience and the learning process which managers go through by performing their managerial duties. As skills are intangible and difficult to codify and articulate, learning by doing remains the key (Castanias \& Helfat, 1991). Although books and other sources of knowledge can be useful, building managerial skills essentially entails exercising the managerial duty (Harris \& Helfat, 1997). Consequently, empirical applications and extensions of the managerial rents model have essentially used managerial experience as a proxy for managerial capital (e.g., Adner \& Helfat, 2003; Bailey \& Helfat, 2001; Harris \& Helfat, 1997; Helfat \& Bailey, 2005; Sturman, Walsh, \& Cheramie, 2007). 
Drawing on this line of work and on the resource-based view of the firm, many scholars have sought to empirically address the link between managerial skills and abilities and rent generation. For example, studying a sample of technology-based firms, Kor and Mahoney (2005) found that firms whose executives had extensive firm-specific experience were in a better position to reap the economic returns of their $R \& D$ investments. Similarly, Ployhart and colleagues (2011) showed using the context of restaurant chains the importance of generic and unit-specific human capital in enhancing firms' ability to generate superior performance. Holbrook, Cohen, Hounshell, and Klepper (2000) demonstrated that the success or failure of new semiconductor companies could be partly explained by the prior career experience of their founders. Sturman and colleagues (2007) examined the extent to which certain types of firm-specific skills could be transferable to other firms and generate value for competing firms. In a similar vein, Holcomb and colleagues (2009) corroborated the claim that managers could be a significant source of value creation. Using the context of professional football and focusing on industry-specific skills, the authors showed that managerial abilities could have a significant bearing on how firms synchronize their resources to achieve a performance advantage.

\section{The Managerial Rents Model: Sowing the Seed for its Own Extensions}

Based on this review, I identify two sets of interrelated questions that arise, one concerning the typology of managerial skills and the second regarding the nature of skills in the managerial rents model. 
First of all, albeit focused primarily on firms' industry, Castanias and Helfat (2001) clearly highlighted the importance of the external environment on the value of skills. In a nutshell, they argued that the environment can dictate which of the four types of skills proposed are more valuable. They also posited that as the environment changes there will be an upheaval with different skills becoming more important. In the 1990s and 2000s, most mainstream management journals were focused on the domestic environment of firms. As the field and the environment firms operate in have evolved, we have become more aware of the importance of the global and national institutional environment of the firm (e.g., Chacar, Newburry, \& Vissa, 2010; Peng, Sun, Pinkham, \& Chen, 2009), in addition to its industry or task environment.

The first question that this paper then asks is: how does the increasing importance of the global environment alter managerial skills that are valuable? Put differently, once the country environment is not assumed to be homogeneous, how does the managerial rents model need to be altered to reflect the changing times? Building on the work of anthropologists (e.g., Levinson \& Malone, 1980), political scientists (e.g., Peters, 2005), sociologists (e.g., Durkheim, 1893; Weber, 1978), and economists (e.g., North, 1991), management scholars have recognized that institutions are more than background conditions and shape firms' behaviors, their competitive advantage, and their performance (e.g., Chacar \& Vissa, 2005; Witt \& Reading, 2009). As such, knowledge or skills on how to operate in these environments are extremely valuable (Hennart, 1988).

Secondly, with their focus on demonstrating the importance of considering managerial skills as a superior resource, Castanias and Helfat were clearly less interested in discussing the nature of skills and their source, ultimately key essential questions. So 
what is the source and nature of managerial skills? Are all managerial skills learned on the job or are there some skills that are learned much before any formal job apprenticeship begins? A number of studies from various fields have highlighted the role of people's childhood and formative years in molding their abilities, values, and norms (Inglehart, 1985; 2000; Schwartz, 1999; Seelhofer, 2010). Therefore, it may important to consider this facet of people's experiences to understand their abilities.

To respond to these two sets of questions, I first draw on institutional theory and argue that similar to the fact that skills could relate to an industry context as noted earlier, they are also likely to be shaped by the broader environment in which managers are embedded, and especially the national institutional environment in which managers are reared. Second, I show that these skills are likely to emanate from different types of experiences rather than just on the job training (Hunter, 1988; Nielsen \& Nielsen, 2013).

\section{EXTENSION OF THE MANAGERIAL SKILLS TYPOLOGY: ADDING COUNTRY-SPECIFIC SKILLS}

Albeit focusing primarily on firms' industry, Castanias and Helfat $(1991 ; 2001)$ exposed the role of firms' external environment in shaping managerial skills. Here I expand on this discussion by highlighting the importance of national institutional environments and by examining the concept of country-specific skills. To begin with, a limited research body, conducted by economists has already introduced the concept of country-specific skills. This research has essentially shed light on immigrants' labor markets exploring workers' human capital and the gaps in pay between immigrants and native workers (e.g., Chiswick, 1978; Duvander, 2001; Friedberg, 2000; Kanas \& Van 
Tuberken, 2009; Kim \& Park, 2013). I build on and extend their work into the managerial arena.

As suggested earlier, just as managers hold skills specific to an industry or to a firm, they are also likely to develop country-specific skills or skills applicable within the realm of a country's institutional environment. CSS could be defined as managers' abilities that are developed in a particular national institutional context. The complex milieu of interrelated informal and formal institutions in which managers are embedded may guide the development of their abilities and knowledge base (Crossland \& Hambrick, 2007; 2011; North, 1990; Witt \& Redding, 2009). According to North (1990), a combination of informal and formal institutions guide individuals in coping with uncertainty, interpreting the environment, and taking suitable actions. The influence of institutions may also manifest in the development of managers' skills; managers embedded in a broader social context may develop beliefs, values, and strategic preferences (e.g., Andrews, 1971) emanating from the informal and formal dimensions of a country's institutional environment.

Starting with informal institutions referring to norms, conventions, and values governing social interactions (North, 1990), I argue that informal rules guide managers' skills by influencing their patterns of thoughts, beliefs, and strategic actions. Informal institutions have commonly been equated to national culture, defined as a system of collectively held beliefs and values (e.g., Dikova, Sahib, \& van Witteloostuijn, 2009; Hofstede, 1980; Hosfstede \& Hosfstede, 2005; Nielsen \& Nielsen, 2013; Van Essen, Heugens, Otten, \& Van Oosterhout, 2012; Witt \& Redding, 2009). A vast body of literature has stressed the importance of national values (referring to "a broad tendency to 
prefer certain states of affairs over others" [Hosftede, 1980, p.19]) in driving economic behaviors and exercising the managerial duty (Hofstede, 2007; Porter, 1990; Ralston, Holt, Terpstra, \& Kai-Cheng, 1997; Witt \& Redding, 2009). It has been argued that executives bring national values and beliefs to their tasks (Baily \& Spicer, 2007). For example, national values shape "elite mentalities" and managers' enduring and profoundly ingrained modes of thoughts disposing them to resort to particular organizational ideologies ${ }^{1}$ (Guillén, 1994; Witt \& Redding, 2009).

Cross-cultural management theorists have also distinguished a plethora of cultural national values. Differences of societal values have been described based on different dimensions such as power distance, individualism versus collectivism, uncertainty avoidance, long-term orientation, performance orientation, etc... (e.g., Hofstede, 1980; House et al., 2004; Schwartz, 1994). For example, collectivism could affect managers' ability to engage in consensus-based decisions and take into consideration multiple stakeholders when making strategic decisions; on the other hand, managers of individualist societies may tend to favor unilateral decision-making (e.g., Aguilera \& Jackson, 2003; Crossland \& Hambrick, 2011; Hofstede, 2007; Guillén, 1994). This heavy emphasis on decision-making based on consensus may explain the reason why in collectivist societies such as Japan, one of the most important selection criteria to hire a manager remains his/her ability to get along with others (Von Glinow, Drost, \& Teagarden, 2002).

\footnotetext{
${ }^{1}$ Aguilera and Jackson (2003) define ideology "as an institutional variable that influences management both by imposing constraints as taken-for-granted world views and by creating normative expectations that become 'focal points' for firm decision making" (458).
} 
Second, CSS may relate to abilities shaped by a country's formal institutions (Nielsen \& Nielsen, 2013; North, 1990). Formal rules are explicit and codified and are composed of economic and social policies, constitutions, laws, and property rights (North, 1990). Formal institutions regulate and govern economic behaviors and may alter firms' strategic decisions (Chacar et al., 2010; Kostova, 1997; North, 1990). They may also affect "information processing and problem solving in executive decision making" (Nielsen \& Nielsen, 2013, p.775). For example, formal rules may influence how economic actors view the role of the government in constraining economic actions. For example, in Japan the general idea that the state should intervene in the economy and provide direction and leadership for the economy is very salient in executives' mind (Witt \& Redding, 2009); compared to US executives who tend to favor minimal governmental economic intervention. Such conceptualizations may have important implications on what managers do in terms of their attempt to change the rules of the game by lobbying and exerting pressure on the government.

Formal rules may also shape firms' mode of governance and managers' conceptualization of firms' raison d' être. For example, in shareholder-oriented countries such as the US or the UK, management contractual responsibility emphasizes the maximization of shareholders' wealth. In other words, managers tend to make decisions based on the premise that "public companies are not in the business to reward creditors, inspire devotion of their employees, win the favor of the communities in which they operate, or have the best products. These are all means to an end - making shareholders richer" (Seely, 1991, p. 35). This perspective departs from that of stakeholder-centered countries in which the corporation is conceptualized as a "social institution whose 
purpose is to further the interests of the corporation itself, typically considering the interests of multiple stakeholders, including shareholders, employees, creditors, customers, and the society" in which it resides (Fiss \& Zajac, 2004, p. 501). This stark difference will likely lead to a different managerial skill development path.

Finally, CSS encompass linguistic abilities (Brannen, 2004; Duvander, 2001; Grinblatt \& Keloharju, 2001; Hambrick, Davison, Snell, \& Snow, 1998). Previous research has indicated the utmost importance of language proficiencies for the conduct of international business (Brannen, 2004; Geringer, 1988; Von Glinow, Shapiro, \& Brett, 2004). Language barriers remain significant impediments to economic exchanges among people from different nations (Ghemawat, 2001; Schmidt \& Sofka, 2009). For example, Geringer (1988) shows the critical role played by mutual language capability on the success of joint ventures. Analogously, Von Glinow and colleagues (2004) demonstrate the extent to which linguistic-related challenges in multicultural teams increase the likelihood of conflicts among team members. Knowing a country's language not only fosters people's ability to communicate, but also enables a manager to grasp the cultural nuances and symbols associated with languages.

\section{EXTENSION OF THE MANAGERIAL SKILLS TYPOLOGY: HOW ARE CSS FORMED?}

Castanias and Helfat $(1991 ; 2001)$ primarily focused on skills acquired through managerial experience as highlighted above. Indeed, managerial experience will be an important driver behind the development of CSS. However, I propose that other types of experiences might be relevant to build skills and particularly CSS. I build on the work of 
Katz (1974) who posits that skills develop not only "through practice" such as professional or career experience but also "through learning related to one's personal experience and background" (98).

Personal experiences could include different facets of an individual's life since his/her birth. Growing-up and spending one's formative years and being educated in a specific country or even in a sub-region within a country may foster the development of learning heuristic and cognitive tools and shape people's values and norms (Berger \& Luckman, 1966; Guillén, 1994; Hambrick et al., 1998; Nielsen \& Nielsen, 2013).

A wealth of research in different academic fields has documented the importance of people's childhood and formative years in molding their values and norms (e.g., Inglehart, 1985; 2000; Schwartz, 1999; Seelhofer, 2010). As observed by Nielsen and Nielsen (2013), "cultural patterns of thinking, feeling, and acting are acquired in early childhood because at that time a person is most susceptible to learning and assimilation" (374). Growing up in a society exposes people to laws, customs, values, scripts, and organizational practices that are imparted through a number of social institutions (e.g., family, schools, the community, workplace, media, etc...) (Hunter, 1988; Markus \& Kitayama, 1994; Schwartz, 1999). This experience cannot be easily replicated through expatriate assignments, especially considering that most of them average less than three years, for practical reasons.

The consequences of embeddedness in a set of formal and informal rules since one's birth are large. For instance, in societies emphasizing the self (e.g., individualistic societies), social institutions operate in a manner that promotes the diffusion of such value to individuals since their birth (Schwartz, 1999). Markus and Kitayama (1994) 
illustrated this process discussing the emphasis placed by parents in North America and Europe on praising children and helping them realize their uniqueness and individuality from their peers. The authors also described this process by highlighting the role played by schooling. Thus, American schools typically give children the opportunity to be recognized for some achievements or to be a "very special person" reinforcing the idea that one is unique and independent from others. This sense of uniqueness and individuality fosters the ability of people to make decisions based on their own judgments as opposed to relying on consensus-based decision making.

In contrast, Japanese schools may stimulate a sense of the self as interdependent with others encouraging students to take group photos or not leave the playgroup until all members of the group are ready to leave (Markus \& Kitayama, 1994). This strong sense of interdependence with others is also likely to lead students to behave similarly. For example, Wiersema and Bird (1993) noted the case of Japanese high school students who were highly judgmental with classmates who had lived outside Japan and exhibited as a result slightly different behaviors from the rest of the group; the authors observed that these students were likely to be ostracized, prompting them to revert to identical behaviors as the rest of the group. Therefore, Japanese executives' inclination to value the collective and to take into account various stakeholders when making decisions is deeply rooted in the values acquired during their formative years (Witt \& Redding, 2009).

There is also evidence that the imprinting effect of people's childhood and formative years is enduring and likely to be significantly anchored in their mind and unlikely to change through subsequent experiences (Inglehart, 1985; 2000; Nielsen \& Nielsen, 2013). Zhou (1997) observes that even when living in another country 
(subsequently), people are very likely to consider their country of origin as a point of reference. This might explain why managers, socialized and exposed from an early age to "the value orientation of their cultural heritage" (Geletkanycz, 1997, p. 618), are strongly influenced by their national culture when making strategic decisions (Crossland \& Hambrick, 2007; 2011). Their mindset is likely to have a strong imprint of their national culture (Geletkanycz, 1997; Schneider \& De Meyer, 1991). Porter (1990) even suggests that by internalizing the norms and cultural values prevailing in their home nation, having been exposed to them for such a long time, managers may take them for granted.

\section{IMPLICATIONS OF CSS}

As observed above, skills may embody the institutionally embedded experiences along an individual's path to becoming a manager (Hambrick et al., 1998; Nielsen \& Nielsen, 2013). While such experiences will always be important, they will become most salient for individuals who have spent a significant number of years in several national institutional environments. I discuss below the implications of CSS for managerial mobility and selection, firm strategy and performance, and managerial compensation. To do so, I primarily draw on key theoretical insights provided by the managerial rents model rooted in RBV. First, the model suggests that managerial skills have an important bearing on the selection and mobility of managers and that such selection will be shaped by firm strategic circumstances (Castanias \& Helfat, 2001). Second, it indicates that the heterogeneity of managerial resources exhibited by skills differentials among managers may prompt them to revert to distinct strategies and strategic actions (leading to different performance implications). Third, the model proposes that superior and heterogeneous 
managerial skills could be a source of competitive advantage and therefore generate superior rent for managers and firms (Castanias \& Helfat, 1991; 2001); superior resources are valuable, rare (or scarce), imperfectly imitable, and imperfectly substitutable (Barney, 1991).

\section{CSS, managerial mobility, and selection}

What is the degree of transferability of CSS across national borders? Since CSS are developed through managers' significant embeddedness in particular national institutional environments, on the one hand it could be argued that their applicability to other institutional environments or their degree of transferability across national borders remains low. Indeed, current research emphasizes the low integration of the executive labor market since firms have a tendency to hire individuals with their home-country specific skills. The skills and abilities required to effectively manage a firm differ significantly across borders (Crossland \& Hambrick, 2007; 2011; Ghemawat, 2007; Hofstede \& Hofstede, 2005).

Examples of such differences abound in comparative management research. For instance, extant research has noted that executives from different countries might need different sets of skills to manage stakeholders (Crossland \& Hambrick, 2007; 2011). In the U.S., it is highly expected that CEOs be able to deal with institutional investors and manage the media (Crossland \& Hambrick, 2007) since firms' behaviors are highly scrutinized by these types of stakeholders. In Japan, such skills are not valued to the same extent since firms receive significantly less media attention. Alternatively, Japanese culture's emphasis on consensus-based decision-making and Japanese stakeholder- 
centered mode of governance may demand that CEOs develop important skills related to their ability to deal with multiple constituents when making strategic decisions (Aguilera \& Jackson, 2003; Crossland \& Hambrick, 2007; 2011; Guillén, 1994; Schneper \& Guillén, 2004).

On the other hand, we have seen during the past few years a growing number of foreign-born executives whose CSS may relate to other countries than firms' country of origin. For example, following the appointment of Indian-born Vikram Pandit, the New York Times pinpointed that he joined the ranks of 14 other foreign-born CEOs in the Fortune 100 firms (NYT, 2007). In a similar vein, Inkpen and Ramaswamy (2005) observed that $10 \%$ of FTSE 100 companies were run by non-nationals in 2003. Not only foreign-born executive appointments are increasing in numbers but also they are spreading to countries once considered impervious to the appointments of any foreigners at any level. A recent Financial Times headline touted "Nomura goes all gaikokujin" in face of its numerous foreign appointees and another "Japan Inc. to continue appointing foreign CEOs" $(F T, 2011)$.

What explains this puzzle? I note that firms' globalization efforts may have changed the degree of transferability of CSS and created a need for companies to appoint leaders with other sets of CSS (Forbes \& Piercy, 1991). Indeed, the increasing globalization of markets and industries has significantly transformed firms' business and competitive landscape and has induced considerable changes in firms' corporate strategy (Forbes \& Piercy, 1991; Wiersema \& Bowen, 2008). More and more firms are expanding their scope beyond their domestic market engaging in international diversification (Wiersema \& Bowen, 2008; 2011). Extant research stresses the central importance of 
executives and human assets in driving the success of multinationals and the economic necessity for such firms to internationalize their corporate suite (Carpenter, Sanders, Gregersen, 2001; Hitt, Tihanyi, Miller, \& Connelly, 2006; Kirca et al., 2011).

Such internationalization needs are likely to alter the skills set sought in top executives. Globalization efforts may strongly encourage firms to seek managers and top executives hailing from outside firms' home country and possessing skills specific to other countries that are of importance to the firm (i.e., are relevant to any parts of their operations be it sales, manufacturing, or other or are relevant to firms' future globalization related efforts). As it is the case for any types of diversification, firms engaging in geographical diversification can achieve superior returns when their diversification efforts match the profile of their human capital (in addition to other resources) (Farjoun, 1994, 1998). More formally:

Proposition 1. Firm geographical diversification will foster the transfer of CSS across national borders.

Proposition 2. Firms pursuing geographical diversification are more likely to consider CSS in the executive selection process.

\section{CSS, firm strategy, and firm performance}

If CSS are distinct from the other three types identified, they are likely to influence managers' performance and the performance of their multinational firms. Below, I consider the implications of CSS for firm performance distinguishing firms' level of performance and the variability of their performance. 


\section{Level of firm performance}

As suggested above, a key insight from the managerial rents model inspired by $\mathrm{RBV}$ is that firms whose managers possess superior skills may achieve above-average performance (Castanias \& Helfat, 1991; 2001). Superior resources could be characterized as (1) valuable, (2) rare (or scarce), (3) imperfectly imitable, and (4) imperfectly substitutable (Barney, 1991).

I argue that CSS could be a source of competitive advantage and constitute a superior resource. First, CSS related to other countries from firms' country of origin could be relatively rare. Everything else being equal, it may be very difficult for firms to find and recruit executives with foreign CSS in the executive labor market (Nielsen \& Nielsen, 2010). In addition, extant research has highlighted the remarkable homogeneity of the corporate suite as it relates to CSS given the lack of global integration of the corporate suite (Crossland \& Hambrick, 2007; Ghemawat, 2007). Most CEOs and top executives are country nationals whose institutional skills are significantly anchored in their home country. For example, in a study conducted using a sample of the largest S\&P 500 firms, Carpenter (2002) indicates that no TMT teams had more than one foreign national.

In addition to being rare, CSS could be valuable. First, foreign CSS could play an important role in shaping the values and cognitive orientation of managers. Executives with foreign CSS have acquired important knowledge of other institutional environments and could be expected to have skills conferring them greater confidence to operate in foreign environments (Sambharya, 1996). Second, CSS could be a source of knowledge about a particular country or region in which firms operate or wish to expand their 
activities (Caligiuri et al., 2004; Nielsen \& Nielsen, 2010). We know that knowledge of institutional environments in which multinationals are present is instrumental for their success and can reduce their liability of foreignness (Zaheer, 1995).

Third, managers with different CSS could bring diversity to the corporate suite and embody a wide range of knowledge and experiences related to various institutional environments (Earley \& Mosakowski, 2000; Nielsen \& Nielsen, 2013). The literature on team diversity suggests that heterogeneous groups are expected to find novel perspectives to non-routines problems such as international diversification (Nielsen \& Nielsen, 2013; Sambharya, 1996). This diversity of CSS could also help firms' executives consider a broader range of information and solutions when making decisions (Hambrick et al., 1998; Sambharya, 1996). Fourth, CSS could foster the formation of a global network since foreign individuals are likely to hold social ties with actors and entities in a particular country or region. These ties could represent an important medium to obtain important market resources and information (Sheng, Zhou, \& Li, 2011). Global expansion often hinges on firms' ability to engage in alliances with foreign partners (Carpenter et al., 2001). Contacts and social ties of CEOs and key executives can often facilitate this alliance formation (Carpenter et al., 2001).

Despite the benefits of appointing individuals with foreign CSS, such executive selection strategy could be imperfectly imitable. First, causal ambiguity could hamper multinationals' efforts to consider foreign CSS in their recruitment strategy (Barney, 1991; Daily, Certo, \& Dalton, 2000; Rumelt, 1974). As argued by Carpenter and colleagues (2001), firms may consider that what is truly needed for them to succeed is to appoint executives with firm-specific skills, industry-specific skills, and generic skills 
such as strategic change management and general leadership skills. Critics often state that "global complexity can be adequately managed through middle management, expatriates, locals, or international consultants" (Carpenter et al., 2001, p. 495). Also, evidence indicates that most firms' operations are much more globalized than their executive suite is $(N Y T, 2007)$.

Second, factors related to unique historical conditions could reinforce the imperfect inimitability of CSS (Barney, 1991). Indeed, certain companies may have developed over the years an organizational culture promoting diversity facilitating the social integration of executives with foreign CSS such as foreign nationals. Appointing foreign executives less rooted in firms' domestic environment could be a testimony of firms' global identity and progressive organizational culture. Such global identity could take years to come to fruition. Coca-Cola exemplifies such global identity. Thus, the company has a long track record of selecting CEOs with foreign roots; it has selected four foreign-born CEOs during the past few years (NYT, 2007).

In sum, if executive CSS are rare, valuable, and imperfectly inimitable, they may have the potential to general superior performance. Hence, I propose:

Proposition 3. Multinationals considering CSS in the executive selection process will outperform their peers.

\section{Variability of firm performance}

As noted earlier, Castanias and Helfat $(1991 ; 2001)$ build on the resource-based view of the firm to emphasize the importance of managerial skills (Barney, 1991). First, the authors state that "managerial resources, defined as the skills and abilities of 
managers, are key contributors to the entire bundle of firm resources that enable some firms to generate rents" (Castanias \& Helfat, 2001, p. 661). Second, they claim that the heterogeneity in managerial resources taking the forms of skills differentials among managers of various firms could lead managers to engage in (and implement) distinctive strategic actions, which in turn produce different performance outcomes.

Relating such heterogeneity argument to CSS, I suggest that multinationals employing executives with various sets of CSS could devise different internationalization strategies leading to different performance outcomes. Indeed, CSS could guide firms' internationalization path and geographic scope. Managers with CSS primarily related to firms' home environment could have a "home bias" or "home-region orientation" and may therefore exhibit a tendency to expand firms primarily in their region of origin (Banalevia \& Dhanaraj, 2013, p. 90). Conversely, managers with CSS related to other regions are likely to make important changes related to firms' operations and presence in these regions (Nielsen \& Nielsen, 2010). Such strategic moves would be expected considering that such managers possess the institutional and cultural knowledge of these regions and likely the relational capital that allows building additional knowledge needed for success (Caligiuri, Lazarova, \& Zehetbauer, 2004).

I argue that such disparity in internationalization paths and geographical scope could have distinct implications for firm performance. Although results are mixed, we know from IB research that firms' geographic scope impact their performance (e.g., Qian, Li, Li, \& Qian, 2008; Qian, Khoury, Peng, \& Qian, 2010; Rugman \& Verbeke, 2004; Wiersema \& Bowen, 2011). Since various geographical scopes could lead to different performance outcomes, and CSS could lead managers to engage in different 
internationalization paths, I propose that CSS may influence the variability of firm performance.

The above arguments led me to formulate the following proposition:

Proposition 4. Differences in CSS lead to differences in the variability of firm performance.

\section{CSS and managerial compensation}

Since superior managerial skills are a source of competitive advantage for firms, it follows that managers holding such skills are likely to receive a pay premium (Castanias \& Helfat, 1991; 2001; Combs \& Skill, 2003; Harris \& Helfat, 1997). While prior studies have examined the superiority of managers' human capital in light of their firm-specific skills, industry-specific skills, and generic skills (Carpenter et al., 2001; Castanias \& Helfat, 2001; Harris \& Helfat, 1997), they have not considered according to my knowledge CSS in the assessment of executives' human capital.

As noted in the preceding sections, CSS may be rare since most executives tend to be country nationals who may bring for the most part CSS related to firms' home country to the executive suite (in addition to the other types of skills previously mentioned). Conversely, executives with foreign CSS contribute to the diversity of the corporate suite and bring heterogeneous CSS to the table, which may be highly valuable to firms operating in multiple countries.

If foreign CSS are valuable and rare and bring heterogeneity to the corporate suite, it ensues that executives embodying such skills may expect to collect rents from this key component of their human capital (Castanias \& Helfat, 2001). Considering the pressing 
needs for many firms to succeed abroad and the importance for such firms to internationalize the corporate suite, foreign CSS could provide executives with negotiation arguments to increase their compensation. Likewise, boards of multinational companies may be willing to grant a higher compensation to individuals who may bring such international diversity to their firms.

In addition, since foreign CSS are relatively rare in the executive labor market, and relatively costly to acquire (Nielsen \& Nielsen, 2010), providing adequate compensation for executives holding these skills could be a way to retain them (Carpenter et al., 2001).

Based on the above-mentioned arguments, I hence propose that multinationals are likely to provide a higher level of total compensation to executives with foreign CSS.

Proposition 5. Foreign CSS generate a premium pay.

\section{DISCUSSION AND CONCLUSION}

Inspired by international business research, I first proposed in this paper an extension to the managerial rents model and the typology of skills that it offers (Castanias \& Helfat, 1991; 2001). Specifically, I stressed the importance of factoring in the role of national institutional contexts into our examination of managerial skills; I maintained that in addition to their firm-specific, generic, and industry-specific skills, managers are likely to have country-specific skills due to their embeddedness in particular institutional environments (Nielsen \& Nielsen, 2013). While the role of cultural and institutional context has been largely surveyed in extant research (Shapiro, Von Glinow, \& Xiao, 
2007), its importance has not been acknowledged in research on managerial skills and managerial resources.

For example, there is a wide recognition in the field of international business that institutional differences shape economic behaviors and affect multinational companies' activities (e.g., Asmussen \& Goerzen, 2013; Dunning \& Lundan, 2009; Peng et al., 2009; Salomon \& Wu, 2012; Von Glinow et al., 2002; Witt \& Redding, 2009). This paper complements this large body of work highlighting the fact that managerial skills are embedded in a large institutional context and positing that such embeddedness may have important implications for the appraisal of managerial resources.

The second extension discussed in this paper concerns the formation of skills. The managerial rents model and human capital theory in general have mainly focused on managers' professional and post-secondary educational experience and its influence on their skills and the value of their human capital; they do not study other types of life experiences that may have a significant bearing on peoples' abilities. This paper argued that in order to examine managers' skills, it may also be important to look at their experience during their formative years. I postulated that growing up and being raised in a particular country may significantly shape people's knowledge and abilities (Luo, 2005; Nielsen \& Nielsen, 2013) and are therefore salient elements of their human capital. This conceptualization departs from that of human capital theory that essentially focuses on educational and professional experience of managers. For example, Nielsen and Nielsen (2010) acknowledge the benefits of hiring individuals with foreign backgrounds for multinational corporations; however, they do not consider abilities acquired during these individuals' formative years as an element of their human capital. Instead, the authors use 
educational and professional experiences as proxies to evaluate their human capital.

Stressing the importance of people's formative years, this paper also contributes to a large body of comparative research that has explored the extent to which growing up in a particular society allows people to be embedded in a number social institutions (e.g., family, schools, the community, workplace, media, etc....) that are likely to shape their values and norms; however, this body of work has not theorized on managers' skills and abilities (Hofstede \& Hofstede, 2005). For example, Markus and Kitayama (1994) documented the impact of various social institutions (e.g., the media, family, and schools) on people's values such as the extent to which they value individualism versus collectivism. Another study conducted by Nielsen and Nielsen (2013) note that growing up in a country molds peoples' cultural patterns of thinking, feeling, and acting without making explicit references to abilities and skills.

Having made such extensions, I then zeroed in on the impact of CSS on managerial mobility and selection, firm strategy and performance, and managerial compensation. First, I proposed that while CSS may limit the mobility of executives across borders, companies' globalization efforts may have changed this picture. Hence, multinationals are more likely to consider the selection of executives with foreign CSS. This proposition is consistent with existing executive succession research recognizing the need for firms to match new executives' skills and backgrounds with their current and future strategic needs (Finkelstein et al., 2009; Kesner\& Sebora, 1994; Wiersema, 1995).

Second, I argued that managers with distinctive CSS might pursue different international strategies that may subsequently have different impact on firm performance. This proposition complements previous studies examining the strategic implications of 
executive successions; a large body of research has documented the impact of skills on executive strategic choices. The premise of this research is that different skills will lead to different strategic actions, which in turn has important implications for firm performance. For instance, it has been argued that managers with firm-specific skills are likely to value the status quo and initiate less strategic change than managers with no firm-specific skills (Chen \& Hambrick, 2012; Kesner \& Sebora, 1994). Wiersema (1992) found that outside CEOs (with no firm-specific skills) were more likely to engage in postsuccession product diversification than insiders.

Third, I proposed that foreign CSS may be rare, valuable, hard to imitate, and substitute; hence, they may lead to superior firm performance and superior managerial compensation. While a wealth research has surveyed the link between superior managerial skills and rent generation, this body of literature has only taken into account generic skills, industry-specific skills, and firm-specific skills (e.g., Kor \& Mahoney, 2005; Ployhart et al., 2011). For example, using the context of restaurant chains, Ployhart and colleagues (2011) investigated generic human capital and unit-specific human capital and their ability to generate superior performance. Similarly, many studies have addressed the impact of superior human capital on managerial compensation. By bringing CSS to the fore and their link to managerial compensation, this study adds another critical factor that decision-makers may need to consider when making compensation decisions.

Alongside the above theoretical implications, discussing country-specific skills may shed light on a growing trend affecting the executive labor market $(F T, 2012)$. In the past, executives' hiring was placed within the context of a national labor market and was made evaluating executives' human capital based on their firm-specific skills, industry- 
specific, and generic skills (e.g., Chen \& Hambrick, 2012; Bailey \& Helfat, 2001; Zhang \& Rajagopalan, 2003; 2004). This study brought to light an additional and important component of human capital that may need to be factored in future research appraising firms' human capital. Furthermore, while extant research explains the lack of global integration of the executive labor market by the low degree of transferability of CSS across borders (e.g., Conyon \& Murphy, 2000; Crossland \& Hambrick, 2007), this study showed that the need of foreign CSS by globalized firms may have started to change this picture.

Finally, this study complements current research on international HR that have highlighted the implications of various global staffing strategies used by multinationals to manage their foreign subsidiaries (e.g., Levy, Beechler, Taylor, \& Boyacigiller, 2007; Perlmutter, 1969; Schneper \& Von Glinow, 2012). Thus, scholars have discussed the fact that multinationals often classified executives and managers according to their skills and mindset which are largely contingent upon where they come from; multinationals are likely to distinguish home-country nationals, local nationals, foreign nationals, and thirdcountry nationals (Kobrin, 1988; McCall \& Hollenbeck, 2002). However, this body of work has been silent on the selection of non-nationals to fill top executives positions at firms' headquarters and the skills that they may bring to the table.

The arguments and propositions advanced here, however, constitute only a first attempt toward the examination of country-specific skills and their importance for firm strategy, managerial selection and compensation, and firm performance. Future research may further the exploration of CSS and address some of the limitations of the current paper. First, I have focused on the implications of CSS as it relates to top executives and 
CEOs. Future studies could extend this research to firm governance. As pinpointed by Castanias and Helfat (2001), the examination of firms' managerial resources should encompass board members since directors are a key component of firms' corporate elites (Jensen \& Zajac, 2004). Indeed, to fulfill their monitoring role (e.g., Fama \& Jensen, 1983) and advisory and counseling roles (e.g., Shen, 2003), board members will most likely need the skills set and ability to comprehend the strategies proposed by top managers (Castanias \& Helfat, 2001; Daily, Ellstrand, \& Johnson, 1996). In the context of geographical diversification, boards members with CSS related to the company's expansion strategies might be an important strategic asset.

Second, my discussion is solely based on the implications of CSS without taking into account their interplay with other types of skills. It may be worthwhile for future research to survey the extent to which CSS might be combined with other forms of human capital specific to a firm and an industry. For example, during the past few years the press has highlighted a few cases of early departures or dismissals of CEOs with foreign CSS because of their lack of firm-specific skills. We could think of the case of the ex-CEO (Craig Taylor) of Nippon Sheet Glass, a Japanese company, who resigned after less than two years in the role because of his fundamental disagreements with the board on the pace and scale of restructuring $(F T, 2012)$. Craig Taylor was appointed at Nippon Sheet Glass after a 36-year career at Dupont.

In a similar vein, it could be argued that CSS may need to be explored in conjunction with other firm resources and strategic resources. As argued by Holcomb and colleagues (2009) building on Castanias \& Helfat's work (2001), "managers and resources jointly determine firm success" (478). 
In short, this study highlights a critical component of managerial human capital that is increasingly prized in the executive labor market as more and more firms are extending their realm across national borders. I hope that this research inspires other researchers to delve further into managers' CSS and their strategic implications. 


\section{REFERENCES}

Adler, P.S. (1993). Time and motion regained. Harvard Business Review, JanuaryFebruary.

Aguilera, R. V., \& Jackson, G. (2003). The cross-national diversity of corporate governance: Dimensions and determinants. The Academy of Management Review, 447465.

Adner, R., \& Helfat, C. E. (2003). Corporate effects and dynamic managerial capabilities. Strategic Management Journal, 24(10), 1011-1025.

Andrews, K. 1971. The Concept of Corporate Strategy, Dow Jones-Irwin, Homewood, Ill.

Asmussen, C. G., \& Goerzen, A. (2013). Unpacking Dimensions of Foreignness: FirmSpecific Capabilities and International Dispersion in Regional, Cultural, and Institutional Space. Global Strategy Journal, 3(2), 127-149.

Bailey, E.E., \& Helfat, C.E. (2001). External management succession, human capital, and firm performance: An integrative analysis. Managerial and Decision Economics, 24(4): 347-369.

Bailey, W. J., \& Spicer, A. (2007). When does national identity matter? Convergence and divergence in international business ethics. Academy of Management Journal, 50(6), $1462-1480$.

Banalieva, E. R., \& Dhanaraj, C. (2013). Home-region orientation in international expansion strategies. Journal of International Business Studies, 44(2), 89-116.

Bartlett, C.A., \& Ghoshal, S. (1989). Managing Across Borders: The Transnational Solution, Boston, MA: Harvard Business School Press.

Barney, J.B. (1991). Firms resources and sustained competitive advantage. Journal of Management, 17(1): 99-120.

Becker, G.S. (1962). Investment in human capital: a theoretical analysis. Journal of Political Economy, 70(5): 9-49.

Berger, P. \& Luckman, T. (1966). The social construction of reality. Garden City, NY: Doubleday.

Brannen, M. Y. (2004). When Mickey loses face: Recontextualization, semantic fit, and the semiotics of foreignness. Academy of Management Review, 29(4), 593-616. 
Caligiuri, P., Lazarova, M., \& Zehetbauer, S. (2004). Top managers' national diversity and boundary spanning: Attitudinal indicators of a firm's internationalization. Journal of Management Development, 23(9), 848-859.

Carpenter, M. A. (2002). The implications of strategy and social context for the relationship between top management team heterogeneity and firm performance. Strategic Management Journal, 23(3), 275-284.

Carpenter, M., Sanders, G., \& Gregersen, H. (2001). Bundling human capital with organizational context: The impact of international assignment experience on multinational firm performance and CEO pay. Academy of Management Journal, 44(3): 493-511.

Castanias, R.P., \& Helfat, C.E. (1991). Managerial resources and rents. Journal of Management, 17(1): 155-171.

Castanias, R.P., \& Helfat, C.E. (2001). The managerial rents model: Theory and empirical analysis. Journal of Management, 27: 661-678.

Chacar, A., \& Vissa, B. (2005). Are emerging economies less efficient? Performance persistence and the impact of business group affiliation. Strategic Management Journal, 26(10): 933-946.

Chacar, A., Newburry, W., \& Vissa B. (2010). Bringing institutions into performance persistence research: exploring the impact of product, financial, and labor market institutions. Journal of International Business Studies, 41: 1119-1140.

Chen, G., \& Hambrick, D. C. (2012). CEO replacement in turnaround situations: Executive (mis) fit and its performance implications. Organization Science, 23(1), 225243.

Chiswick, B. R. (1978). The effect of Americanization on the earnings of foreign-born men. The Journal of Political Economy, 897-921.

Combs, J. G., \& Skill, M. S. (2003). Managerialist and human capital explanations for key executive pay premiums: a contingency perspective. Academy of Management Journal, 46(1), 63-73.

Conyon, M. J., \& Murphy, K. J. (2000). The prince and the pauper? CEO pay in the United States and United Kingdom. The Economic Journal, 110(467), 640-671.

Crossland, C. \& Hambrick, D.C. (2007). How national systems differ in their constraints on corporate executives: A study of CEO effects in three countries. Strategic Management Journal, 28(8): 767-789. 
Crossland, C., \& Hambrick, D. C. (2011). Differences in managerial discretion across countries: how nation-level institutions affect the degree to which ceos matter. Strategic Management Journal, 32(8), 797-819.

Daily, C. M., Certo, S. T., \& Dalton, D. R. (2000). International experience in the executive suite: The path to prosperity? Strategic Management Journal, 21(4), 515-523.

Daily, C.M., Ellstrand, A.E, \& Johnson, J.L. (1996). Boards of directors: a review and research agenda. Journal of Management, 22(3), 409-438.

Dikova, D., Sahib, P. R., \& van Witteloostuijn, A. (2009). Cross-border acquisition abandonment and completion: The effect of institutional differences and organizational learning in the international business service industry, 1981-2001. Journal of International Business Studies, 41(2), 223-245.

Durkheim, E. 1893. The Division of Labor in Society. New York: Free Press.

Duvander, A.E. (2001). Do Country-Specific Skills Lead to Improved Labor Market Positions? : An Analysis of Unemployment and Labor Market Returns to Education among Immigrants in Sweden. Work and Occupations, 28: 210.

Earley, P. C., \& Mosakowski, E. (2000). Creating hybrid team cultures: An empirical test of transnational team functioning. Academy of Management Journal, 43(1), 26-49.

Fama, E.F. \& Jensen, M.C. (1983). Separation of ownership and control. Journal of Law and Economics, 26: 301-325.

Farjoun, M. (1994). Beyond industry boundaries: Human expertise, diversification and resource-related industry groups. Organization Science, 5(2), 185-199.

Farjoun, M. (1998). The independent and joint effects of the skill and physical bases of relatedness in diversification. Strategic Management Journal, 19(7), 611-630.

Financial Times. (2011). Nomura goes all gaikokujin. May 26.

Financial Times. (2012). Nippon Glass’s American chief resigns. April 18.

Finegold, D., Benson, G. S., \& Mohrman, S. A. (2002). Harvesting What They Grow: Can Firms Get a Return on Investments in General Skills?. Organizational Dynamics, 31(2), 151-164.

Finkelstein, S., Hambrick, D. C., \& Cannella, A. A. 2009. Strategic Leadership: Theory and Research on Executives, Top Management Teams, and Boards. Oxford University Press, USA. 
Fiss, P. C., \& Zajac, E. J. (2004). The diffusion of ideas over contested terrain: The (non) adoption of a shareholder value orientation among German firms. Administrative Science Quarterly, 49(4), 501-534.

Forbes, J. B., \& Piercy, J. E. (1991). Corporate mobility and paths to the top: Studies for human resource and management development specialists Greenwood Publishing Group.

Friedberg, R. M. (2000). You can't take it with you? Immigrant assimilation and the portability of human capital. Journal of Labor Economics, 18(2), 221-251.

Geletkanycz, M.A. (1997). The salience of 'culture's consequences: the effects of cultural values on executive commitment to the status quo. Strategic Management Journal, 18(8): 615-634.

Geringer, J. M. (1988). Partner selection criteria for developed country joint ventures. Business Quarterly, 53(2): 79-90.

Ghemawat, P. (2001). Distance still matters. Harvard business review, 79(8), 137-147.

Ghemawat, P. (2007). Redefining global strategy: crossing borders in a world where differences still matter. Boston, MA: HBS Press.

Graham, J. R., Li, S., \& Qiu, J. (2012). Managerial attributes and executive compensation. Review of Financial Studies, 25(1), 144-186.

Grinblatt, M., \& Keloharju, M. (2001). How distance, language, and culture influence stockholdings and trades. The Journal of Finance, 56(3), 1053-1073.

Groysberg, B., McLean, A. N., \& Nohria, N. (2006). Are leaders portable? Harvard Business Review, 84(5), 92.

Groysberg, B., Sant, L., \& Abrahams, R. (2008). When 'stars' migrate, do they still perform like stars?. MIT Sloan Management Review, 50(1), 41-46

Guillén, M.F. (1994). Models of management: Work, authority and organization in comparative perspective. Chicago: University of Chicago Press.

Hambrick, D. C., Davison, S. C., Snell, S. A., \& Snow, C. C. (1998). When groups consist of multiple nationalities: Towards a new understanding of the implications. Organization Studies, 19(2), 181-205.

Hannan, M. T., \& Freeman, J. (1977). The population ecology of organizations. American journal of sociology, 82(5), 929-964. 
Hannan, M. T., \& Freeman, J. (1984). Structural inertia and organizational change. American sociological review, 49(2), 149-164.

Harris, D. \& Helfat, C. (1997). Specificity of CEO human capital and compensation. Strategic Management Journal, 18, 895-920.

Helfat, C. E., \& Bailey, E. E. (2005). External succession and disruptive change: Heirsapparent, forced turnover and firm performance. Strategic Organization, 3(1), 47-83.

Hennart, J.F. (1988). A Transaction Costs Theory of Equity Joint Ventures. Strategic Management Journal, 9(4), 361-374.

Hitt, M. A., Tihanyi, L., Miller, T., \& Connelly, B. (2006). International diversification: Antecedents, outcomes, and moderators. Journal of Management, 32(6), 831-867.

Hofstede, G. (1980). Culture's consequences: International differences in work-related values (Vol. 5). Sage Publications, Incorporated.

Hofstede, G. (2007). Asian management in the 21st century. Asia Pacific journal of management, 24(4), 411-420.

Hofstede, G., \& Hofstede, G. J. (2005). Cultures and organizations, software of the mind, intercultural cooperation and its importance for survival. McGraw-Hill: New York.

Holbrook, D., Cohen, W. M., Hounshell, D. A., \& Klepper, S. (2000). The nature, sources, and consequences of firm differences in the early history of the semiconductor industry. Strategic Management Journal, 21(10-11), 1017-1041.

Holcomb, T.R., Holmes, R.M., \& Connelly, B.L. (2009). Making the most of what you have: managerial ability as a source of resource value creation. Strategic Management Journal, 30, 457-485.

House, R. J., Hanges, P. J., Javidan, M., Dorfman, P. W., \& Gupta, V. (2004). Leadership, culture, and organizations: The GLOBE study of 62 societies. Beverly Hills: Sage Publications.

Hunter, A.A. (1988). Formal education and initial employment: unraveling the relationships between schooling and skills over time. American Sociological Review, 53(5): 753-765.

Inglehart, R. (1985). Aggregate stability and individual-level flux in mass belief systems: The level of analysis paradox. The American Political Science Review, 79(1), 97-116.

Inglehart, R. (2000). Globalization and postmodern values. Washington Quarterly, 23(1), $215-228$. 
Inkpen, A.C., \& Ramaswamy, K. (2005). Global strategy: creating and sustaining advantage across borders. London, Oxford University Press.

Jensen, M., \& Zajac, E.J. (2004). Corporate elites and corporate strategy: how demographic preferences and structural position shape the scope of the firm. Strategic Management Journal, 25(6): 507-524.

Kanas, A., Van Tubergen, F., \& Van der Lippe, T. (2009). Immigrant Self-Employment Testing Hypotheses About the Role of Origin-and Host-Country Human Capital and Bonding and Bridging Social Capital. Work and Occupations, 36(3), 181-208.

Katz, R.L. (1974). Skills as an effective administrator. Harvard Business Review, 52: 90102.

Kesner, I. F., \& Sebora, T. C. (1994). Executive succession: past, present \& future. Journal of Management, 20(2), 327-372.

Kim, J., \& Park, J. (2013). Foreign Direct Investment and Country-Specific Human Capital. Economic Inquiry, 51(1), 198-210.

Kirca, A. H., Hult, G. T. M., Roth, K., Cavusgil, S. T., Perryy, M. Z., Akdeniz, M. B., ... \& White, R. C. (2011). Firm-specific assets, multinationality, and financial performance: a meta-analytic review and theoretical integration. Academy of Management Journal, 54(1), 47-72.

Kobrin, S. J. (1988). Expatriate reduction and strategic control in American multinational corporations. Human Resource Management, 27(1), 63-75.

Kor, Y. Y., \& Mahoney, J. T. (2005). How dynamics, management, and governance of resource deployments influence firm - level performance. Strategic Management Journal, 26(5), 489-496.

Kostova, T. (1997). Country institutional profiles: Concept and measurement. Academy of Management Proceedings, 1997(1), 180-184.

Levinson D, Malone MJ. (1980). Toward Explaining Human Culture: A Critical Review of the Findings of Worldwide Cross-Cultural Research. HRAF Press: New York.

Levy, O., Beechler, S., Taylor, S., \& Boyacigiller, N. A. (2007). What we talk about when we talk about 'global mindset': Managerial cognition in multinational corporations. Journal of International Business Studies, 38(2), 231-258.

Lieberson, S., \& O'Connor, J. F. (1972). Leadership and organizational performance: A study of large corporations. American sociological review, 117-130. 
Luo, Y. (2005). How does globalization affect corporate governance and accountability? A perspective from MNEs. Journal of International Management, 11(1), 19-41.

Mackey, A. (2008). The effect of CEOs on firm performance. Strategic Management Journal, 29(12), 1357-1367.

Markus, H. R., \& Kitayama, S. (1994). A collective fear of the collective: Implications for selves and theories of selves. Personality and Social Psychology Bulletin, 20(5), 568579 .

Marshall, A. (1890). Principles of economics (Vol. 1). Wirtschaft und Finanzen.

McCall, M. W., \& Hollenbeck, G. P. (2002). Developing global executives: The lessons of international experience. Harvard Business School Pr.

Murphy, K. J., \& Zabojnik, J. (2004). CEO pay and appointments: A market-based explanation for recent trends. The American Economic Review, 94(2), 192-196.

Neal, D. (1995). Industry-specific human capital: Evidence from displaced workers. Journal of labor Economics, 13(4), 653-677.

New York Times. (2007). Foreign-born chiefs reflect Fortune 100's global reach. December 12.

Nielsen, S., \& Nielsen, B. B. (2010). Why do firms employ foreigners on their top management team? An exploration of strategic fit, human capital and attraction-selectionattrition perspectives. International Journal of Cross Cultural Management, 10(2), 195209.

Nielsen. S., \& Nielsen, B.B. (2013). Top management team nationality diversity and firm performance: a multilevel study. Strategic Management Journal, 34: 373-382.

North, D. C. (1990). Institutions, institutional change and economic performance. Cambridge university press.

North, D. (1991). Institutions. Journal of Economic Perspective, 5(1): 97-112.

Peng, M. W., Sun, L.S., Pinkham, B., \& Chen, H. (2009). The institution-based view as a third leg for a strategy tripod. The Academy of Management Perspectives, 23(3), 63-81.

Perlmutter, H. V. (1969). The tortuous evolution of the multinational corporation. Columbia Journal of World Business, 4(1): 9-18.

Peters, B.G. (2005). Institutional Theory in Political Science: The New Institutionalism. Bloomsbury. 
Ployhart, R. E., Van Iddekinge, C. H., \& MacKenzie, W. I. (2011). Acquiring and developing human capital in service contexts: The interconnectedness of human capital resources. Academy of management journal, 54(2), 353-368.

Porter, Michael E. (1990). Competitive Advantage of Nations. New York, Free Press.

Qian, G., Li, L., Li, J., \& Qian, Z. (2008). Regional diversification and firm performance. Journal of International Business Studies, 39(2), 197-214.

Qian, G., Khoury, T. A., Peng, M. W., \& Qian, Z. (2010). The performance implications of intra-and inter-regional geographic diversification. Strategic Management Journal, 31(9), 1018-1030.

Ralston, D. A., Holt, D. H., Terpstra, R. H., \& Kai-Cheng, Y. (1997). The impact of national culture and economic ideology on managerial work values: A study of the United States, Russia, Japan, and China. Journal of International Business Studies, 28(1), 177-207.

Rugman, A. M., \& Verbeke, A. (2004). A perspective on regional and global strategies of multinational enterprises. Journal of International Business Studies, 35(1), 3-18.

Rumelt, R. P. (1974). Strategy, structure, and economic performance. Boston, MA:

Division of Research, Graduate School of Business Administration, Harvard University.

Sambharya, R. B. (1996). Foreign experience of top management teams and international diversification strategies of US multinational corporations. Strategic Management Journal, 17(9), 739-746.

Schmidt, T., \& Sofka, W. (2009). Liability of foreignness as a barrier to knowledge spillovers: Lost in translation?. Journal of International Management, 15(4), 460-474.

Schwartz, S. H. (1994). Beyond Individualism-Collectivism: New cultural dimensions of values. In U. Kim, H.C. Triandis, C. Kagitcibasi, S-C. Choi, \& G. Yoon (Eds.), Individualism and collectivism: Theory, method and applications (pp.85-119). London: Sage.

Schwartz, S. H. (1999). A theory of cultural values and some implications for work. Applied psychology, 48(1), 23-47.

Schneider, S. C., \& De Meyer, A. (1991). Interpreting and responding to strategic issues: The impact of national culture. Strategic Management Journal, 12(4), 307-320.

Schneper, W. D., \& Guillén, M. F. (2004). Stakeholder rights and corporate governance: A cross-national study of hostile takeovers. Administrative Science Quarterly, 49(2), 263295. 
Schneper, W. D., \& Von Glinow, M.A. 2013. Cultural Attitudes in Multinational Corporations in Eric. H. Kessler (editor) Encyclopedia of Management Theory. Thousand Oaks, CA: Sage Publications, pp. 173-176.

Seelhofer, D. (2010). New brooms: The stock market reaction to foreign CEO succession in switzerland. European Journal of International Management, 4(5), 506-523.

Seely, M. (1991). A vision of value-based governance. Directors and Boards, 15(3), 3536.

Shapiro, D. L., Von Glinow, M. A., \& Xiao, Z. (2007). Toward polycontextually sensitive research methods. Management and Organization Review, 3(1), 129-152.

Shen, W. (2003). The Dynamics of the CEO-Board Relationship: An Evolutionary Perspective. The Academy of Management Review, 28(3): 466-476.

Sheng, S., Zhou, K. Z., \& Li, J. J. (2011). The effects of business and political ties on firm performance: Evidence from China. Journal of Marketing, 75(1), 1-15.

Steiner, G.A., Miner, J.B. \& Gray, E.R. (1986). Management policy and strategy, $\left(3^{\text {rd }}\right.$ ed.). New York: Macmillan.

Sturman, M. C., Walsh, K., \& Cheramie, R. A. (2007, August). Firm-explicit human capital: understanding the value of transferable firm knowledge in the labor marketplace. In Academy of Management Proceedings (Vol. 2007, No. 1, pp. 1-6). Academy of Management.

Salomon, R., \& Wu, Z. (2012). Institutional distance and local isomorphism strategy. Journal of International Business Studies, 43(4), 343-367.

Thomas, A. B. (1988). Does leadership make a difference to organizational performance?. Administrative Science Quarterly, 33(3), 388-400.

Van Essen, M., Heugens, P. P., Otten, J., \& Van Oosterhout, J. H. (2012). An institutionbased view of executive compensation: A multilevel meta-analytic test. Journal of International Business Studies, 43(4), 396-423.

Von Glinow, M. A., Drost, E. A., \& Teagarden, M. B. (2002). Converging on IHRM best practices: Lessons learned from a globally distributed consortium on theory and practice. Human Resource Management, 41(1), 123-140.

Von Glinow, M. A., Shapiro, D. L., \& Brett, J. M. (2004). Can we talk, and should we? Managing emotional conflict in multicultural teams. Academy of Management review, 29(4), 578-592. 
Wang, H. C., \& Barney, J. B. (2006). Employee incentives to make firm-specific investments: implications for resource-based theories of corporate diversification. Academy of Management Review, 31(2), 466-476.

Wasserman, N., Nohria, N., \& Anand, B. N. (2001). When does leadership matter? The contingent opportunities view of CEO leadership (Working Paper No. 02-04). Retried from Harvard Business School website: http://dx.doi.org/10.2139/ssrn.278652

Weber, M. 1978. Economy and Society. Berkeley, CA: University of California Press.

Wiersema, M. F. (1992). Strategic consequences of executive succession within diversified firms. Journal of Management Studies, 29(1), 73-94.

Wiersema, M. F. (1995). Executive succession as an antecedent to corporate restructuring. Human Resource Management, 34(1), 185-202.

Wiersema, M. F., \& Bird, A. (1993). Organizational demography in Japanese firms: Group heterogeneity, individual dissimilarity, and top management team turnover. Academy of Management Journal, 996-1025.

Wiersema, M.F., \& Bowen, H.P. (2008). Corporate diversification: the impact of foreign competition, industry globalization, and product diversification. Strategic Management Journal, 29(2): 115-132.

Wiersema, M. F., \& Bowen, H. P. (2011). The relationship between international diversification and firm performance: Why it remains a puzzle. Global Strategy Journal, 1: $152-170$.

Witt, M.A., \& Reading, G. (2009). Culture, meaning, and institutions: Executive rationale in Germany and Japan. Journal of International Business Studies, 40, 859-885.

Yukl, G. A. (1981). Leadership in organizations. Prentice Hall.

Zaheer, S. (1995). Overcoming the liability of foreignness. Academy of Management journal, 38(2), 341-363.

Zhang, Y., \& Rajagopalan, N. (2003). Explaining new CEO origin: Firm versus industry antecedents. Academy of Management Journal, 46(3), 327-338.

Zhang, Y., \& Rajagopalan, N. (2004). When the known devil is better than an unknown god: An empirical study of the antecedents and consequences of relay CEO successions. Academy of Management Journal, 47(4), 483-500.

Zhou, M. (1997). Growing up American: the challenge confronting immigrant children and children of immigrants. Annual Review of Sociology, 23: 63-95. 


\title{
Firms' Current and Future Strategic Needs and Foreign-Born CEO Successions
}

\author{
ABSTRACT \\ For the past decades, scholars have paid significant attention to surveying the \\ organizational antecedents of various types of CEO successions. A key insight in this \\ research is that firms tend to appoint new CEOs whose skills and abilities are in line with \\ their current and future strategic needs. Drawing on this literature, I explore the \\ organizational antecedents of foreign-born CEO successions. I first note the role played \\ by firms' existing strategic context in driving the selection of foreign-born CEOs. As \\ firms expand abroad, the necessity to internationalize the corporate suite and appoint \\ leaders with deep knowledge of foreign institutional environments and less strictly \\ focused on firms' domestic environment becomes salient. Second, I theorize on the \\ importance of firms' future strategic needs and propose that firms that are likely to \\ internationalize or increase their international expansion may value the skills and \\ abilities offoreign-born CEOs. Using a sample of 253 CEOs appointed from 2005 to \\ 2010 at the helm of Global 500 companies, I find support for some of my hypotheses.
}

\section{INTRODUCTION}

CEO succession research has provided rich insights about why firms choose CEOs external to their firms and/or to their industry (e.g., Kesner \& Sebora, 1994; Zhang \& Rajagopalan, 2003), two phenomena that used to be rare in large companies only a couple of decades ago but have since become more common (Finkelstein, Hambrick, \& 
Canella, 2009). This research stream generally builds on the premise that firms try to match new CEOs' skills and abilities with their organizational contexts and future strategic needs (e.g., Datta \& Guthrie, 1994; Pfeffer \& Salancik, 1978; Vancil, 1987). More specifically, it postulates that changing firm needs lead to changes in CEOs' profile and the skills associated with that profile, be it general, firm-specific, or industry-specific skills (e.g., Castanias \& Helfat, 1991; 2001).

I argue in this paper that such general principle would apply in the case of a nascent phenomenon: the rise of foreign-born or non-national CEOs. By foreign-born, non-native, or non-national CEOs, I mean individuals who were born and spent their formative years ${ }^{2}$ in a country other than their firm's country of origin (Hambrick, Davidson, \& Snell, 1998). We have seen a dramatic rise in the selection of such individuals and more recently at the helm of global firms albeit their hire is still seen as heretic in a number of countries. In a 2007 article, the New York Times reported that 15 Fortune 100 companies were led by non-national CEOs (NYT, 2007a). In my own data, I find that $18 \%$ of all firms that entered the fortune's Global 500 ranking from 2005 to 2010 were led by a non-national CEO.

In order to explain this rising phenomenon, I first argue that the managerial skills model needs to be extended to include country-specific skills (CSS) as an additional element of the managerial skill typology (Castanias \& Helfat, 1991; 2001). Similar to how firm-specific skills originate from embeddedness in a firm, country-specific skills are shaped through embeddedness in a country. More specifically, CSS refer to managers' knowledge and abilities that are applicable and specific to a particular national

\footnotetext{
${ }^{2}$ Formative years refer to the experience of an individual from his/her birth to when he/she reaches 17.
} 
institutional context. CSS could include language (Duvander, 2001), values, and a mindset shaped by a country's institutional environment. CSS could also relate to expertise in dealing and building relationships with suppliers, customers, regulators, and other key stakeholders in a particular country.

Once this extension to the managerial skills model is made, I shift attention to the international context of the firm as an important driver in the selection of CEOs. Indeed, as firms consider internationalization as a way to grow, and as they become more international, the need for a chief executive with a deep understanding of foreign institutional environments becomes more pressing. Often times, this need is counterbalanced by the tendency to hire country nationals who may be better able to understand the firm's home country, and typically its center of gravity. As internationalization pressures increase and competition grows, non-nationals become more attractive candidates to the CEO position. Nationals with international skills provide valuable skills that are relatively rare, but not so unique considering that the typical international experience of a CEO is about 2 years (Carpenter, Sanders, \& Gregersen, 2001). On the other hand, foreign-born individuals come to the job with institutional knowledge related to countries and regions other than firms' home country and region; their focus and orientation are likely to be less entrenched in firms' home nation. Ultimately, each CEO follows strategies that are built on their own skills, leading them in a different direction, creating the heterogeneity that could provide the firm with a competitive advantage (Castanias \& Helfat, 2001).

More specifically, I maintain that a high level of internationalization will increase the attractiveness of a CEO with country-specific skills other than home-country based. 
As such, as firms increase their internationalization, there will be an increased likelihood of hiring non-national CEOs (H1). An increase of non-national successions will also be observed in firms that are likely to face internationalization pressures, regardless of their current level of internationalization. Examples of such firms would be companies with a high product diversification level that may be observing the limits to product scope economies $(\mathrm{H} 2)$, or high growth firms that may face similar diseconomies when pursuing national growth only $(\mathrm{H} 3)$.

I test the above hypotheses examining new CEOs appointed at the helm of firms part of the Global 500 ranking between 2005 and 2010. My final sample includes 253 new CEO appointments in 222 unique public firms located in 27 countries. After controlling for country, firm, and industry effects, and executives' international, educational, and professional experience, I find support for some of my hypotheses.

The results of the study show the power of extant theory on the importance of matching managerial skills to strategic and organizational needs and the necessity of adjusting CEO skills when firm strategy requires change (Datta \& Guthrie, 1994; Gupta, 1984; Kesner \& Sebora, 1994; Vancil, 1987). The findings also bring full-on the importance of understanding institutional environments of countries outside of a firm's home country at every level of the organization (e.g., Nielsen \& Nielsen, 2010; 2013). Furthermore, the findings highlight the possibility that hiring a manager embedded in a different institutional environment brings a set of managerial skills that may constitute a resource diversity to the firm. From a practical standpoint, this study shows that the selection of foreign-born CEOs is not a fad or a bandwagon; instead, it may be a phenomenon driven by real strategic needs and the limited potential for most nationals to 
be deeply embedded in other national institutional environments. This would explain the appointments of notorious CEOs like Indra Nooyi who brought a unique strategy to PepsiCo and pushed for increased market penetration in developing countries.

I proceed in the rest of the paper as follows. I first review the literature on CEO succession relevant to the phenomenon of interest by emphasizing the organizational antecedents to CEO selections. Second, I elaborate on the theory proposed in this research. Third, I describe the study data, methods, and measures. Finally, I discuss my results and conclude.

\section{ORGANIZATIONAL ANTECEDENTS TO CEO SUCCESSION}

To examine the antecedents of non-national successions, I build on previous research linking organizational factors to various types of successions, which I review below.

Succession research lies in the premise that "CEO succession outcomes should reflect the antecedent conditions found in organizations" (Datta \& Guthrie, 1994, p. 569). Therefore, many studies have addressed the link between organizational factors and the characteristics of newly selected CEOs (or different types of succession) (e.g., Datta \& Guthrie, 1994; Zhang \& Rajagopalan, 2003) emphasizing the need for selection committees to match new CEOs' skills and characteristics with firms'strategic needs (e.g., Finkelstein et al., 2009; Giambatista et al., 2005; Kesner \& Sebora, 1994). The idea of "fit" has been salient in this research suggesting that "executive transition was more effective if the characteristics of the successor matched the characteristics of the firm and its environment” (Kesner \& Sebora, 1994, p. 361). 
During the CEO succession process, boards often evaluate potential market opportunities and threats and the corresponding skills that might be needed to develop such opportunities (Finkelstein, Hambrick, \& Canella, 1996; Vancil, 1987). The board seeks "to match the skills of each candidate to the forward-looking skill needs of the corporation" (Vancil, 1987).

Many studies have documented the link between organizational characteristics and new CEOs' skills and background. Table 1 below provides a summary of some key studies that emphasize the idea that firms tend to match the skills and profile of new CEOs with their organizational and strategic needs.

Table 1: Matching CEO skills to Firm's Current and Changing Needs

\begin{tabular}{|l|l|l|}
\hline \multicolumn{1}{|c|}{ CEO Skill/Background } & \multicolumn{1}{c|}{ Firm Profile } & \multicolumn{1}{c|}{ Example of Studies } \\
\hline $\begin{array}{l}\text { Production/marketing } \\
\text { background }\end{array}$ & Internal diversifying firms & Song (1982) \\
\hline Legal/financial & Acquisitive diversifying firms & Song (1982) \\
\hline Financial background & Diversifying firms & Fligstein (1987) \\
\hline Technical background & Innovative firms & Datta \& Guthrie (1994) \\
\hline $\begin{array}{l}\text { Technical and financial, } \\
\text { marketing, administrative }\end{array}$ & $\begin{array}{l}\text { Maturing technology-based } \\
\text { firms }\end{array}$ & Drazin \& Kazanjian (1993) \\
\hline Operations background & Declining performance & Ocasio and Kim (1999) \\
\hline $\begin{array}{l}\text { External CEOs (with no } \\
\text { firm-specific skills) }\end{array}$ & Poorly performing firms & $\begin{array}{l}\text { Allen, Paniam, \& Lotz (1979); } \\
\text { Boeker \& Goodstein (1993); } \\
\text { Canella \& Lubatkin (1993); } \\
\text { Dalton \& Kesner (1985); } \\
\text { Finkelstein et al. (2009); Zhang } \\
\text { \& Rajagopalan (2004) }\end{array}$ \\
\hline $\begin{array}{l}\text { Relay successors (with } \\
\text { firm-specific skills) }\end{array}$ & Highly performing firms & Zhang \& Rajagopalan (2004) \\
\hline Managerial background & Firms in pre-IPO stage & Li \& Canella (2003) \\
\hline International experience & Multinational firms & Magnusson \& Boggs (2006) \\
\hline $\begin{array}{l}\text { General management and } \\
\text { financial background }\end{array}$ & $\begin{array}{l}\text { Firms pursuing the following } \\
\text { strategic types: defenders, } \\
\text { prospectors, and analyzers }\end{array}$ & Snow \& Hrebiniak (1980) \\
\hline
\end{tabular}


While several organizational predictors to CEO succession have been discussed in extant research, prior firm performance has received a great deal of attention (e.g., Boeker, 1992; Boeker \& Goodstein, 1993; Datta \& Guthrie, 1994; Giambatista et al., 2005; Kesner \& Sebora, 1994). Poor performance has been highlighted to be an important antecedent to intra/outside firm successions. Finkelstein and colleagues (2009) note that "the most obvious potential predictor of whether or not a new CEO will come from the outside is the performance of the organization in the period before the succession" (187). Firms with poor performance are likely to hire an external CEO, with no firm-specific skills, as the latter might be perceived "as more able than insiders to initiate and implement strategic changes" (Canella \& Lubatkin, 1993, p. 763). The assumption is that such lack of firm-specific skills brings a fresh perspective or fresh blood to the company (Bigley \& Wiersema, 2002; Chung \& Luo, 2013; Finkelstein et al., 2009; Zhang \& Rajagopalan, 2010).

Besides its relevance to intra-firm and outside-firm successions, organizational performance has been linked to other types of successor characteristics. For example, Ocasio and Kim (1999) found that a decline of performance was associated with the appointment of CEOs with operations background. Zhang and Rajagopalan (2004) concluded that poor performance is negatively associated with the appointment of a relay successor, or one in which "incumbent CEO works with an heir apparent and passes the baton of leadership to the heir" - since poor performance might lead the board to question the capabilities of the existing TMT (including the heir) to remedy the situation (483). 
Several other organizational characteristics have also been linked to new CEOs' characteristics. Zhang and Rajagopalan (2003) found that strategic persistence enhances the likelihood of an intra-firm succession since it demands firm-specific skills (making internal hiring desirable). Song (1982) demonstrated the link between corporate diversification strategy and new CEOs' functional backgrounds. The author showed that highly diversified firms pursuing organic growth were more likely to appoint CEOs with production/marketing experience vis-à-vis highly diversified firms engaging in M\&As that were more likely to value executives with legal/financial experience. Datta and Guthrie (1994) indicated that innovative firms tend to hire CEOs with primary experience in technical functional areas since individuals with these backgrounds are more likely to understand such firms' core operations and technologies. In a similar vein, Drazin and Kazanjian (1993) demonstrated that technology-based companies that are in their growth phase were more likely to appoint CEOs with a technical background vis-à-vis firms in their mature stage that tended to have CEOs with financial, marketing, and administrative expertise.

This study draws on this body of work to take the realm of this research from the national context to the international arena; I examine the strategic contexts leading firms to hire foreign-born CEOs who may bring other sets of skills and abilities to the table. I first expand on these skills and abilities and elaborate on my theoretical model in the subsequent section. 


\section{NON-NATIONAL VERSUS NATIONAL CEO SUCCESSIONS}

Before discussing the strategic antecedents of non-national successions, I expand below on the types of skills and abilities that non-national CEOs are likely to embody.

As noted previously, board members are likely to consider new CEOs' skills and their fit to firms' strategic needs when making hiring decisions (Vancil, 1987).

Castanias and Helfat (1991; 2001) developed a typology of managerial skills that is useful in organizing past work. In this typology, they build on human capital theory to propose that managerial skills are comprised of firm-specific skills, industry-specificskills, or generic skills. It seems that when board members review candidates' human capital, they are likely to examine these managerial skills when making hiring decisions (Castanias \& Helfat, 1991; 2001).

CEO succession research has highlighted the importance of firm-specific skills when considering internal versus external CEOs (e.g., Canella \& Lubatkin, 1993; Shen \& Canella, 2002). In addition, the literature has paid attention to industry-specific skills when considering CEOs' industry origin (e.g., Zhang \& Rajagopalan, 2003), and generic skills such as CEOs' functional and educational background (e.g., Datta \& Guthrie, 1994). Firm-specific skills are valuable and rare and can help firms gain a competitive advantage (Castanias \& Helfat, 1991) albeit when great change is necessary they may hamper change efforts (Baily \& Helfat, 2003). Industry-specific skills are also of a valuable nature; hiring external CEOs from the same industry is likely to increase the chance of learning from the strategies and practices of competitors in the same industry (Zhang \& Rajagopalan, 2003). Generic skills such as for examples executives' ability to set a vision 
for a firm or their leadership skills are highly valued; their absence may put firms at a competitive disadvantage (Barney, 1991).

What skills and abilities do foreign-born managers bring to the table? In order to examine this question, I argue that in addition to firm-specific, industry-specific, and generic skills, we need to consider an additional dimension of managerial skills - what I call country-specific skills (CSS).

CSS relate to skills that originate from an individual's embeddedness in a national institutional context (Duvander, 2001) and refer to managers' abilities and knowledge that are applicable and specific to a particular national institutional context. CSS could also include an individual's language (Brannen, 2004; Duvander, 2001; Von Glinow, Shapiro, \& Brett, 2004) and an individual's values and mindsets that are shaped by the formal and informal institutional environment in which he/she is embedded (Crossland \& Hambrick, 2007; Hofstede \& Hofstede, 2005; Nielsen \& Nielsen, 2013). They are for the most part acquired through growing-up, being educated, and spending one's formative years in a specific country (Nielsen \& Nielsen, 2013). As argued by Nielsen and Nielsen (2013), "cultural patterns of thinking, feeling, and acting are acquired in early childhood because at that time a person is most susceptible to learning and assimilation" (374). Such patterns are likely to be significantly anchored in somebody's mind and are unlikely to change through subsequent experiences (Hofstede \& Hofstede, 2005; Nielsen \& Nielsen, 2013). For example, CEOs, socialized and exposed from an early age to "the value orientation of their cultural heritage" (Geletkanycz, 1997, p. 618) might be strongly influenced by their national culture when making strategic decisions (Crossland \& Hambrick, 2007; 2011). 
Nationals can become embedded in other institutional contexts, developing skills and knowledge related to other institutional environments. But as a Siemens executive told me in an interview, "spending two to four years in Brazil does not mean that you understand well how Brazil operates." While international professional experience changes the knowledge and skill profile of a manager, it may not be as fundamental as the skills and abilities shaped by imprinting (Caligiuri \& DiSanto, 2001; Nielsen \& Nielsen, 2010). Even when living in another country (subsequently), people are likely to consider their country of origin as a point of reference (Zhou, 1997). This might explain why nationality has been recognized as a "superordinate determinant of identity" and a determinant likely to be even more salient than characteristics such as race, gender, and other "status-determining traits" (Dahlin, Weingart, \& Hinds, 2005, p.1111).

Hence, two individuals born and raised in two different countries are likely to have a different set of country-specific skills, as two managers socialized in two different firms will acquire distinct sets of firm-specific skills. Such skills will not only be specific to a particular country but also related to a region (in an $\mathrm{n}$ dimensional space) in which an individual's country is located. For examples, French nationals are often more familiar with French speaking countries and areas and their institutions, such as the French speaking part of Canada or Lebanon (Ronen \& Shenkar, 1985). English men and women are more familiar with countries that were part of the British colonial empire, such as the English Speaking part of Canada and Australia (Ronen \& Shenkar, 1985). In a similar vein, individuals from developing countries, with often less developed and enforced laws, tend to understand better how such institutional environments operate (Cuervo-Cazurra \& Genc, 2008). 
In addition to foreign CSS, I argue that foreign CEOs might embody the ability to bring a unique global perspective to firms given their increased international background. Being exposed to two or more cultural systems having been raised in a foreign country and living in a different country from their country of origin, foreign CEOs may be able to understand foreign cultures with ease (an important success factor for geographically diversified firms) and to bridge among different national cultures. In addition, research (stemming from psychology) on individuals significantly exposed to more than one set of cultural schemas suggests that such individuals may possess a rich behavioral repertoire and a strong ability to develop complex cultural representations (La Frambroise, 1993; Brannen \& Thomas, 2010; Nguyen \& Benet-Martínez, 2007). Such complex cultural representations might enable foreign CEOs to exhibit a high level of cross-cultural literacy and intercultural sensitivity (Nguyen \& Benet-Martínez, 2007).

The example of Carlos Ghosn is often cited when referring to a leader whose cultural adaptability and unique global personal experience (being born and raised in Brazil and being the CEO of Renauld-Nissan) have conferred him unique skills to manage a very complex organization composed of two companies coming from very distant institutional environments (Japan and France) (Birkinshaw, Brannen, \& Tung, 2011). In an interview conducted by CNN in 2008, Carlos Ghosn noted that without his multinational background, he would not have been so successful at managing both companies. 


\section{Strategic Antecedents to Non-National CEO Successions}

What types of firms are likely to choose a non-national CEO succession? The theoretical premise of this paper is that two facets of strategic contexts may prompt firms to select a non-national CEO. The first dimension relates to firms' existing strategic needs. I argue that firms with greater levels of international involvement may face important internationalization-related challenges and are likely to value the unique country-specific skills and knowledge that a foreign-born leader brings (Brannen \& Thomas, 2010; Nielsen \& Nielsen, 2013). The second facet concerns firms' anticipated strategic needs. Since board members usually make hiring decisions based on their anticipations of firms' future strategy, I propose that organizations that are likely to internationalize or those that are likely to increase their internationalization may also value the skills that non-nationals may possess. Examples of such companies include firms susceptible to experience limitations or diseconomies in their current strategies following product diversification and high levels of organizational growth.

Figure 1 summarizes the conceptual framework that I propose in this research and on which I elaborate below.

Figure 1: Conceptual Model

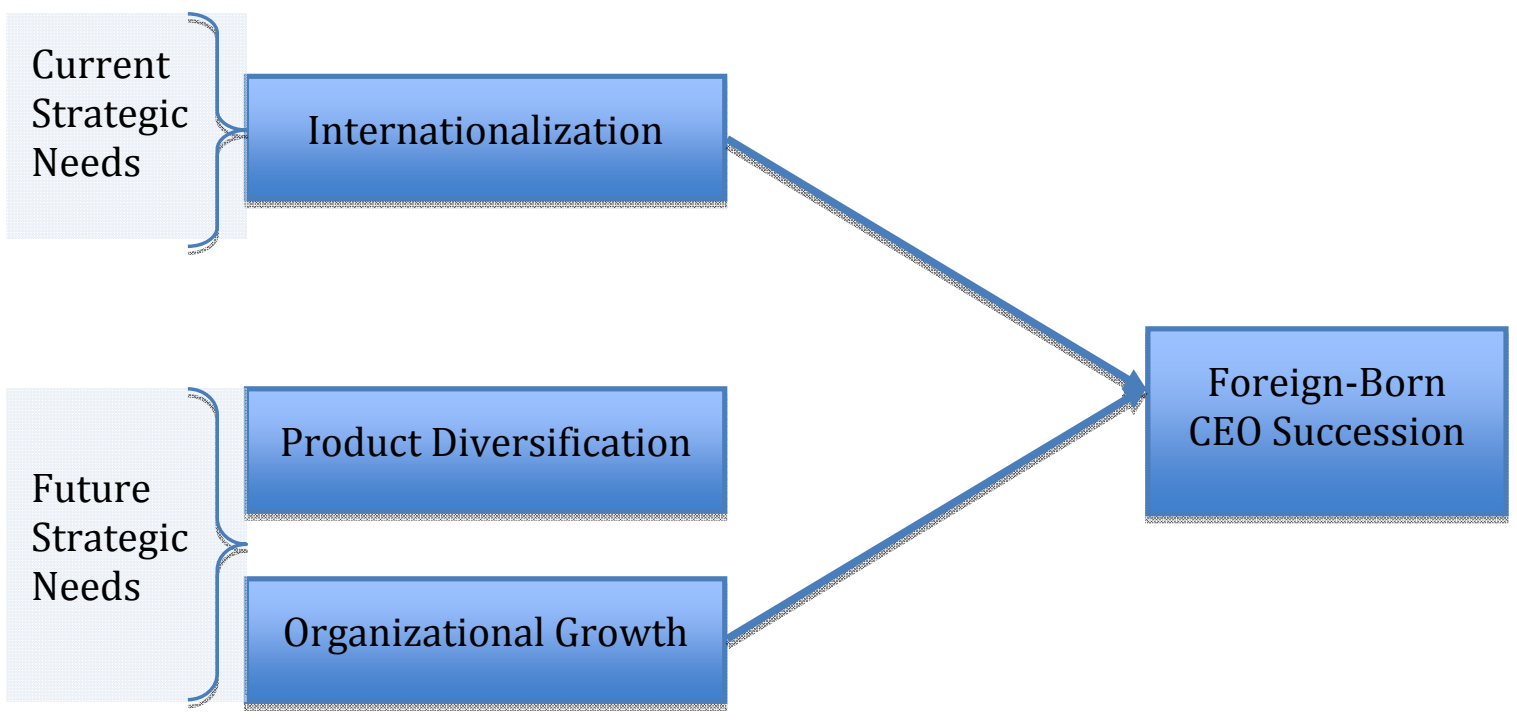




\section{Current Strategic Needs}

I posit here that the choice between a foreign-born versus a national candidate is influenced by the relative importance of firms' international operations. Although greater internationalization could represent a significant source of business and economic opportunities (Contractor, Kundu, \& Hsu, 2003; Hitt, Hoskisson, \& Kim, 1997), it poses important challenges for managers. First, dealing with different cultural and institutional environments and various competitive landscapes (Kostova, 1997; Sanders \& Carpenter, 2008) requires that managers overcome their domestic myopia and likely ethnocentric mindset (or home-country orientation) (Levy, Beechler, Taylor, \& Boyacigiller, 2007; Perlmutter, 1969). Drawing on their strengths, managers tend to rely on the experience and repertoires of routines developed in their domestic environment (Barkema \& Vermeulen, 1998) - which may or may not be adequate to manage across borders. Nadkarni, Herrmann, and Perez (2011) point to the fact that managers are likely to use their domestic mindsets as "reference points", "cognitive filters", and "knowledge repertoires" when managing firms' global operations (511). While managers may eventually develop enough institutional knowledge about other institutional settings from their home country, it takes time to form complex institutional and cultural understanding that would enable them to manage in a way that transcend their home-nation's culture and institutional environment (Levy et al., 2007).

Third, despite the need for multinational corporations to hire leaders with significant international experience, evidence suggests that such managerial skills and abilities remain rare and costly. For example, Carpenter and colleagues (2001) note that the "direct or indirect costs of acquiring and retaining an internationally-seasoned CEO 
may be prohibitive" (496). The authors highlight the limited number of top executives with significant international professional experience that are available in the executive labor market. Moreover, individuals with international experience tend to have relatively more limited and homogenous experience resulting from a couple of short assignments abroad (Magnusson \& Boggs, 2006; Nielsen \& Nielsen, 2010; Ondrack, 1985).

I propose that the limited number of internationally seasoned executives and the difficulty inherent in transitioning their strategic focus from a national to a global one may create the need for firms to consider the appointment of individuals who do not hail from their home country. Firstly, such individuals add heterogeneity to firms' managerial resources known to create a potential to generate a competitive advantage (Castanias \& Helfat, 1991; 2001). Being born and raised in a foreign country and having lived in firms' home country might confer foreigners a different set of cultural knowledge and insight, value systems, and psychological make-up (Hambrick et al., 1998) that could be beneficial for multinational companies. When these executive skills are combined with firm-specific resources, they have a potential to distinguish a firm's strategy from that of its competitors and to increase the expected value of its strategy. Note here that there may also be important risks associated with such strategy as exemplified with the fast departure of many foreign CEOs such as Howard Springer, the ex-CEO of Sony.

Second, considering that their country-specific skills may not relate to firms' home country, foreign-born CEOs may be able to understand the formal and informal institutions of firms' existing and potential operations in their countries/regions of origin (Duvander, 2001; Nielsen \& Nielsen, 2010; 2013). For example, when Vikram Pandit was appointed at the head of Citigroup in 2007, the New York Times reported that one of 
the key factors (besides his analytical skills) that made him the best candidate for the position was his knowledge of emerging markets coming from India (NYT, 2007b).

Despite firms' pressing need to internationalize the C-suite, such changes may not happen overnight since firms might be reluctant at first to hire an individual who is not at the image of their national origin (Duvander, 2001). Howard Anderson (professor at the Sloan school) commenting on the hiring of foreign-born CEOs in the US observed in a New York Times interview that "some corporate boards might still not be comfortable with foreign-born chief executives because they feel they have more in common with another American" (NYT, 2007a). In addition to such homophilic tendencies (Zajac \& Westphal, 1996), boards might take time to adjust their top executives recruitment strategy and to redefine the skills set sought in a new leader considering the difficulty associated with breaking established routines (Hannan \& Freeman, 1984). Therefore, I propose that boards of companies with a higher level of internationalization will be more prone to recognize the need to appoint a foreign-born CEO.

Finally, operating in a large number of countries, highly internationalized firms are likely to be exposed to a more nationally-diverse executive labor market (Nielsen \& Nielsen, 2013) which might enhance the likelihood of hiring a foreign-born CEO. Therefore, I formally propose the following hypothesis:

Hypothesis 1. There is a positive relationship between a firm's level of internationalization and the likelihood of a foreign-born CEO succession. 


\section{Anticipated Strategic Needs}

As discussed earlier, board members could make hiring decisions based on their anticipation of firms' future strategic needs (Giambatista et al., 2005). In addition to firms that already have a strong international footprint, firms that may internationalize or may increase their international presence might consider the appointment of a foreignborn CEO. I postulate that firms with a high level of product diversification and those that are growing rapidly are likely to fit such profile.

Indeed, firms pursuing growth can often achieve their goal via national expansions. Firms can also diversify their product portfolio. Product diversification refers to expansion into new product areas and has been a popular corporate strategy especially among large firms (Hitt, Hoskisson, \& Ireland, 1994).

While such strategies can be fruitful, they can both ultimately encounter limits as it relates to their potential. In the case of product diversification, many firms discover the limits to diversification due to the unrelatedness of the product markets in which they operate or the inability to generate economies of scope across divisions. Indeed, extant research suggests that product diversification does not significantly enhance firm performance (especially in the case of unrelated diversifiers) (Chatterjee \& Wernerfelt, 1991; Hitt et al., 1994; Kim, Hwang, \& Burgers, 1989; Palich Cardinal, \& Miller, 2000).

Considering such challenges, geographic diversification may become a viable strategic option available to firms seeking to enhance their performance. Indeed, research has shown that product diversified firms (related and unrelated) can increase their performance by diversifying internationally (Hitt, Hoskisson, \& Ireland, 1994; Kim et al., 1989). Hitt and colleagues (1994) postulate that international diversification could help 
product diversified firms exploit economies of scale and scope and achieve interdependencies across product areas, and therefore enhance their performance. Similarly, Parkhe (1991) maintains that the simultaneous consideration of product and geographic diversification is critical for companies to realize an optimal allocation of resources. This proposition has been supported empirically. For example, Kim and colleagues (1989) found that geographical diversification moderates the relationship between product diversification and performance. Their findings also indicated that unrelated diversifiers with a high level of geographical diversification achieved higher corporate profit growth than unrelated diversifiers with low geographical diversification. Since internationalization could be an important source of business and growth opportunities for product diversifiers, such firms are likely to seek the necessary managerial resources to handle their international endeavors. This will increase the likelihood of hiring a national CEO with significant international experience but also a foreign-born CEO. The number of candidates to the chief executive position with significant international experience is known to be limited (Carpenter et al., 2001). In a world of trade-offs, non-nationals can bring foreign country-specific skills and the deep knowledge it takes to operate in a region.

Hence, I formulate the following hypothesis:

Hypothesis 2. There is a positive relationship between a firm's level of product diversification and the likelihood of a foreign-born CEO succession.

In the case of organizational growth, a high level of organizational growth implies that a firm might run out of domestic opportunities. Therefore, international growth might 
become a promising option and appointing a foreign-born CEO might be beneficial since he/she might be a suitable candidate to implement firms' international growth strategy.

This desire to grow their foreign operations might create a strong need for these firms to internationalize the executive suite by appointing a foreign-born leader (NYT, 2007a). Given their foreign country-specific skills, foreigners might be thought to be capable of carrying out firms' international growth strategies. The hiring of foreign-born CEOs may also increase the cultural diversity of the corporate suite that could be beneficial to international expansion. Evidence suggests that foreign-born CEOs are likely to hire other foreign-born executives (Nielsen \& Nielsen, 2010). For example, Sidney Taurel, the Moroccan-born ex-CEO of Eli Lilly (a US pharmaceutical giant), is well known for his strong commitment to globalize the company's C-suite by tapping into talent from all over the world. Two years after his appointment to the post of CEO, half of the senior executives working at Eli Lilly's headquarter were foreign.

In addition, foreign-born CEOs' international experience and foreign national origin might also serve as a strong signal of firms' commitment to global expansion and international growth. I therefore hypothesize that:

Hypothesis 3. There is a positive relationship between a firm's level of organizational growth and the likelihood of a foreign-born CEO succession. 


\section{METHODS}

I test in this study the drivers of the selection of a foreign-born or non-national CEO. Given the dichotomous nature of the independent variable, I employed logistic regression to test the hypotheses, lagging the explanatory variables by one year in line with previous succession research (e.g., Zhang \& Rajagopalan, 2003). I also checked the robustness of my findings using mixed effect logistic regression methodology to control for the nested structure of the data (as multiple successions might have occurred within one company). The results are unchanged.

Below is an overview of the sample selection procedure, the data sources, and the measures used in the study.

\section{Data}

The starting sample for this study was all firms listed in the Fortune Global 500 ranking from 2005 to 2010 resulting in a total of 689 unique firms from 36 countries. 156 firms were then removed as they were privately-held, state-owned, or subsidiaries of other firms. 376 CEO succession events were then identified for the remaining 533 firms. Information on CEO names and appointment dates came mostly from the Fortune Global 500 website. Missing names were collected from multiple sources including the Directory of Corporate Affiliations, Corporate Library (for US firms), Hoovers, and companies' annual reports.

The primary sources of data used to obtain information on CEOs' appointments were the Directory of Corporate Affiliations, companies's annual reports and $20 \mathrm{~F}$, companies's website, Lexis Nexis, Business Week Executive Profile, Hoovers, Who's Who in Business and Finance, and Bloomberg. From these data sources, I could also gather 
information on the national origin and career and educational experience of 293 CEOs. Information about firm and industry level characteristics was found from Bloomberg, Capital IQ (a Standard and Poor's database), companies's annual reports and 20F, Worldscope (a Thomson Reuters' database) and Compustat Segment. After merging the firm and industry level data collected, I could obtain a final sample of 253 CEO successions taking place in 222 unique firms (located in 27 countries). 194 of these firms experienced one succession, 25 two successions, and the remaining 3 firms had three succession events in the six-year period of the study.

Table 2: Successions Characteristics per Year

\begin{tabular}{|l|c|c|c|c|c|c|}
\hline Year & 2005 & 2006 & 2007 & 2008 & 2009 & 2010 \\
\hline Number of succession events & 34 & 50 & 56 & 48 & 37 & 28 \\
\hline $\begin{array}{l}\text { Percentage of non-national } \\
\text { successions }\end{array}$ & $24 \%$ & $22 \%$ & $16 \%$ & $25 \%$ & $32 \%$ & $25 \%$ \\
\hline
\end{tabular}

\section{Measures}

\section{Criterion Variable}

Foreign-Born CEO Succession. This is a dummy variable taking a value of 1 if a CEO was born and raised in a country other than his/her firm's country of origin and 0 otherwise. CEO nationality was collected from various CEO biographical sources including Hoovers, companies's annual reports and 20F, Bloomberg, Lexis Nexis, and Who's Who in Business and Finance, and a 1000 CEOs. The location of a firm's headquarter was gathered from Compustat North America, Compustat Global, Bloomberg, and Capital IQ. 3 firms had dual headquarters and were assigned to the 
oldest headquarter's country for convenience. Out of the 253 successions observed, I could identify 59 foreign-born CEO successions. The table below provides more details about the breakdown of successions per year.

\section{Explanatory Variables}

Firm Level of Internationalization. This construct is measured by the degree of internationalization (DOI), a commonly used measure of a firm's foreign involvement. DOI is the share of foreign operations within a firm (Tihanyi, Griffith, \& Russell, 2005) measured by its foreign sales ratio or a firm's foreign sales divided by its total sales (e.g., Geringer, Beamish, \& daCosta, 1989; Wiersema \& Bowen, 2008). The data to compute this ratio were obtained from firms' annual reports and 20F, Capital IQ, and Bloomberg. Product Diversification. Product diversification is measured by Jacquemin and Berry's (1979) entropy measure of diversification. This entropy is defined as $\sum \mathrm{i}[\mathrm{Pi} \mathrm{x} \ln (1 / \mathrm{Pi})]$, where Pi refers to the proportion of a firm's sales attributable to segment $i$ and $\ln (1 / \mathrm{Pi})$ is the weight attributed to each segment (e.g., Hitt et al., 1997; Wiersema \& Bowen, 2008). It takes into account the number of product segments in which a firm operates and the proportion that each segment represents in a firm's total sales. Firms' sales were classified according to their four-digit Standard Industrial Classification (SIC); number of segments reported by firms varied from 1 to 10 . Product segment sales were obtained from Worldscope and Capital IQ.

Organizational Growth. This variable is measured by the percentage change in firms' total sales from one year preceding the succession over the two years preceding the succession event (Datta \& Guthrie, 1994). Sales data were obtained from Bloomberg. 


\section{Control Variables}

Various firm, industry, time, CEO, and country controls were included to the statistical models to rule out potential alternative explanations. I controlled for fixed firm effects; in addition, the study controls for prior firm performance and firm size. Firm fixed effects intend to correct for the potential lack of independence of observations since as indicated above a firm could experience multiple successions within the period under consideration in this paper. Although all firm-level and industry-level variables are measured at $\mathrm{t}-1$, prior firm performance is measured at $\mathrm{t}-2$ as poor prior performance has been shown to be a determinant of succession (e.g., Kesner \& Sebora, 1994). To operationalize firm performance, I used adjusted return on assets (ROA) defined as a focal firm's ROA adjusted by its industry ROA. Data for firms' ROA and industry ROA were collected through Bloomberg.

Firm size, an important determinant of CEO succession (Grusky, 1963; Kesner \& Sebora, 1994), was operationalized using the natural logarithm of total assets. Other measures of sizes such as the natural logarithm of sales and employees were also considered for robustness check as described below. All measures of size were obtained from Bloomberg. I controlled for firms' country of origin given that patterns of CEO recruitments vary across countries (Crossland \& Hambrick, 2007; 2011). The study also controlled for year of hire operationalized by the year in which a CEO was appointed (Zhang \& Rajagopalan, 2003).

At the industry level, a control is made for the level of an industry's competitiveness by including a measure of industry concentration. This variable is captured by the four-firm concentration ratio for a company's main Global Industry 
Classification Standard $\left(\mathrm{GICS}^{3}\right)$ (Chacar, Vissa, \& Newburry, 2009). Data to calculate this ratio were collected through Bloomberg.

At the CEO level, I controlled for CEOs' company of origin, a dummy variable taking a value of 0 if a new $\mathrm{CEO}$ has had at least two years of tenure in the hiring firm and 1 if the new CEO was externally appointed. There were 61 external successors and 192 internal CEOs. Past research has highlighted the importance of $C E O s^{\prime}$ international experience especially in the context of multinational companies (Carpenter et al., 2001; Sambharya, 1996).

To quantify international experience, I followed previous research and created a factor taking into account CEOs' educational and professional experience outside their home country and their firm's country of origin. The factor is composed of the following three indicators: 1) educational experience 2) number of years spent abroad 3) number of countries in which an individual worked. I also controlled for other CEO characteristics such as age and industry of origin. They are excluded from the results for simplicity since the results of the study remained unchanged when they were included in the analysis.

\section{RESULTS}

Table 2 presents the descriptive statistics and correlation matrix. Since the correlation between international experience and product diversification was greater than 0.30 in absolute value, I examined the data to detect potential threats of multicollinearity. I computed variance inflation factors (VIFs) and found a mean VIF of 1.18; no VIF was

\footnotetext{
${ }^{3}$ GISC distinguishes 24 industry groups.
} 
superior to 2.13 suggesting that there is no collinearity threat among the independent variables (Kleinbaum, Kupper, \& Muller, 1988). 
Table 3: Summary Statistics and Zero-Order Correlation Coefficients

\begin{tabular}{|c|c|c|c|c|c|c|c|c|c|c|c|c|c|}
\hline Variables & Mean & SD & 1 & 2 & 3 & 4 & 5 & 6 & 7 & 8 & 9 & 10 & 11 \\
\hline 1. Foreign CEO Dummy & 0.24 & 0.43 & 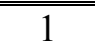 & & & & & & & & & & \\
\hline 2. Firm Size & 10.28 & 0.85 & -0.01 & 1 & & & & & & & & & \\
\hline 3. Adjusted ROA & -0.04 & 3.86 & 0.02 & 0.02 & 1 & & & & & & & & \\
\hline 4. External CEO Dummy & 0.24 & 0.43 & 0.21 & -0.08 & -0.04 & 1 & & & & & & & \\
\hline 5. CEO's Intl. Experience & 4.26 & 7.00 & 0.24 & 0.07 & 0.16 & 0.25 & 1 & & & & & & \\
\hline 6. Industry Concentration & 0.25 & 0.10 & 0.03 & 0.14 & 0.00 & -0.06 & 0.07 & 1 & & & & & \\
\hline 7. Free Cash Flow & $\begin{array}{c}1706.7 \\
3\end{array}$ & $\begin{array}{c}15065 . \\
58\end{array}$ & 0.04 & 0.12 & 0.04 & 0.04 & 0.05 & -0.00 & 1 & & & & \\
\hline 8. Year of Hire & $\begin{array}{c}2007.3 \\
5\end{array}$ & 1.55 & 0.05 & 0.14 & 0.04 & 0.04 & 0.03 & -0.20 & 0.11 & 1 & & & \\
\hline 9. DOI & 0.39 & 0.27 & 0.2 & 0.23 & 0.09 & 0.02 & 0.29 & 0.01 & 0.02 & 0.07 & 1 & & \\
\hline 10. Pdt. Diversification & 0.61 & 0.53 & 0.08 & 0.13 & -0.08 & -0.02 & 0.10 & -0.32 & 0.00 & -0.06 & 0.16 & 1 & \\
\hline 11. Organizational Growth & 9.28 & 26.57 & 0.13 & 0.02 & 0.15 & 0.00 & 0.09 & -0.00 & -0.03 & -0.11 & -0.02 & 0.04 & 1 \\
\hline
\end{tabular}


Table 3 presents the results of the logistic regression. In Model 1, or base model, only the control variables are included. In Model 2 (3 and 4 respectively), I tested the relationship between DOI (product diversification and organizational growth, respectively) and the likelihood of a foreign-born CEO succession. Model 5 presents the results of the full model.

Table 4: Drivers of Foreign-Born CEO Appointment

\begin{tabular}{|c|c|c|c|c|c|}
\hline Variables & Model 1 & $\begin{array}{l}\text { Model } 2 \\
\end{array}$ & Model 3 & Model 4 & Model 5 \\
\hline \multicolumn{6}{|l|}{ Control variables } \\
\hline Industry Concentration & 1.282 & 1.888 & 2.600 & 1.388 & $3.013^{\dagger}$ \\
\hline Firm and Country fixed-effects & Inc. & Inc. & Inc. & Inc. & Inc. \\
\hline Adjusted ROA & -0.007 & -0.006 & 0.000 & -0.020 & -0.016 \\
\hline Firm Size & -0.026 & -0.185 & -0.123 & -0.033 & -0.265 \\
\hline Free Cash Flow & -0.000 & -0.000 & -0.000 & -0.000 & -0.000 \\
\hline External CEO dummy & $0.810^{*}$ & $1.126 * *$ & $0.869 *$ & $0.812 *$ & $1.167^{*}$ \\
\hline CEO's Intl. Experience & $0.064 * *$ & 0.033 & $0.060 * *$ & $0.065 * *$ & 0.031 \\
\hline Year of Hire & 0.102 & 0.087 & 0.139 & 0.129 & 0.148 \\
\hline \multicolumn{6}{|l|}{ Predictor variables } \\
\hline DOI (H1) & & $3.046^{* * *}$ & & & $3.156^{* * *}$ \\
\hline Product Diversification $(\mathrm{H} 2)$ & & & $0.621^{\dagger}$ & & 0.446 \\
\hline Organizational Growth (H3) & & & & $0.011 *$ & $0.013 *$ \\
\hline $\mathrm{N}$ & 253 & 253 & 253 & 253 & 253 \\
\hline Likelihood ratio chi-square & 26.25 & 46.90 & 29.72 & 29.78 & 53.47 \\
\hline Pseudo-r ${ }^{2}$ & 0.095 & 0.170 & 0.1082 & 0.108 & 0.194 \\
\hline Log likelihood & -124.283 & -113.960 & -122.547 & -122.51 & -110.675 \\
\hline
\end{tabular}

Note: $\left({ }^{\dagger}\right) p<0.1 ;\left(^{*}\right) p<0.05 ;\left(^{* * *}\right) p<0.01 ;\left(^{* * * *}\right) p<0.001$

In model 1 , the coefficients for two control variables are statistically significant namely CEOs' company of origin and international experience. These results indicate that foreign-born CEOs are more likely to be externally appointed and have more international experience than national CEOs. International experience loses its statistical significance in models 2 to 5 ; but the sign of its coefficient remains positive. 
Overall, the results obtained in model 2 to 5 lend support to this study's overall theoretical premise that firms' existing and future strategic context will be significantly related to the likelihood of a foreign-born CEO succession. In hypothesis 1, I argue that there is a positive relationship between a firm's level of internationalization and the likelihood of a foreign-born CEO succession. As model 2 shows, DOI is statistically significant $(\mathrm{p}<0.001)$ and the sign of the coefficient is positive supporting H1. The results of model 3 provide support for $\mathrm{H} 2(\mathrm{p}<0.10)$ positing that there is a positive relationship between product diversification and the likelihood of a foreign-born CEO succession. However, as shown in model 5 , product diversification loses its significance when entered in the full model so $\mathrm{H} 2$ is not supported. In Model 4, I tested the relationship between organizational growth and the likelihood of a non-national CEO succession. The results support this hypothesis $(\mathrm{p}<0.05)$. In model 5 (full model), the sign and significance of DOI and organizational growth remain unchanged, indicating the stability of the findings for $\mathrm{H} 1$ and $\mathrm{H} 3$.

\section{Post hoc analysis and robustness checks}

I performed an additional battery of tests to check the robustness and stability of my findings. The first set of tests concerns the use of alternative operationalizations of some control variables. I reran the models using adjusted ROE as an alternative measure of firm performance. The results remained unchanged. Similarly, I tested the hypotheses using different measures of firm size such as log of assets and log of employees and found identical results.

In the second series of tests, I introduced other control variables. Following succession research stressing the role played by previous CEOs in the succession process 
(e.g., Finkelstein et al., 2009; Zhang \& Rajagopalan, 2003), I added to my models a variable capturing whether or not the previous CEO (prior to the succession) was foreign. Previous CEO national origin is a dummy variable taking a value of 1 if the previous CEO was born and raised in a country other than his/her firm's headquarter country and 0 otherwise. I identified firms' previous CEOs using Bloomberg, Directory of Corporate Affiliations, and companies' annual reports and 20F. To find previous CEOs' national origin, I used the same sources as the ones employed to find the national origin of newly appointed CEOs. The results were in line with the ones reported in the earlier section. I also controlled for industry globalization measured by the average foreign sales ratio of each firm's primary industry (Carpenter et al., 2001). Data collected from Computat Segments were used to compute this variable. The results were also consistent with prior findings.

\section{DISCUSSION AND CONCLUSION}

Scholars have examined the selection of CEOs from different backgrounds and origins and their fit with firms' strategic needs and profiles. Following on their footsteps, I examined a new phenomenon: the appointment of foreign-born CEOs. The results obtained in this study demonstrated that with increased levels of internationalization, the likelihood of hiring a non-national to the chief executive position increases, highlighting the importance of country-specific skills, a set of skills that has not yet received due attention in the literature. These results complement a burgeoning area of study whereby researchers have examined executives' national origins and have explored national 
diversity and its consequences in the context of TMTs or boards of directors (e.g., Nielsen \& Nielsen, 2010; 2013; Ramaswamy \& Li, 2001).

These findings are also in line with prior work showing the influence of firms' strategic context on CEO successions (Datta \& Guthrie, 1994; Finkelstein et al., 2009; Kesner \& Sebora, 1994). Various types of successions (e.g., intra-firm/outside-firm successions, intra-industry/outside-industry successions) and their determinants have been studied in extant research (e.g., Finkelstein et al., 2009; Kesner \& Sebora, 1994; Zhang \& Rajagopalan, 2003); but, very little is known about non-national CEO successions and their organizational antecedents. The realm of CEO succession research has been largely confined to the domestic setting and to the examination of CEOs' company and industry origins. This study adds to this body of literature and highlights the importance of considering CEOs' national origin and its implications for CEO selection.

In addition to exploring firms' current strategic and organizational needs, I focused my attention on firms' future strategic developments - knowing that such factors may drive executive hiring (Vancil, 1987). I hypothesized that firms experiencing a high level of organizational growth are likely to run out domestic opportunities and may therefore consider a leader with deep knowledge of foreign institutional environments such as a non-national individual. The results corroborated this claim.

This study complements previous research exploring executives' international professional experience (Carpenter et al., 2001; Daily, Certo, \& Dalton, 2000; Sambharya, 1996) by emphasizing the importance of national origin as a key element of executives' profiles. Although some scholars alluded to the importance of executives' national origin 
in their research, the appointment of foreign leaders was too rare to study in large scale empirical research (Carpenter, 2002; Carpenter et al., 2001). Carpenter and colleagues (2001) demonstrated that globalization-related challenges are a major impetus for this change. Second, this study complements extant research on bi-culturalism conducted primarily by psychologists and cross-cultural management theorists who have largely concentrated their efforts on studying bi-cultural employees and have neglected top executives (e.g., Brannen \& Thomas, 2010). Third, on a methodological note, this study, by taking into account CEOs' formative years, proposes an improved measure of national origin; prior research (e.g., Nielsen \& Nielsen, 2013) has only taken into account individuals' place of birth ignoring therefore their formative years.

As a first attempt to assess the strategic antecedents to foreign-born CEO selection, the paper has limitations offering important avenues for future research. First, my sample is composed of the largest global firms introducing a potential size bias in the analysis and limiting the external validity of this research. In addition, a majority of the largest publicly traded global firms come from developed markets limiting also the generalizability of the findings. Second, as noted by Nielsen \& Nielsen (2013), "while nationality is a powerful analytical construct, it is not completely deterministic as other factors may influence an individual's institutionally embedded experiences" (380). Given the secondary nature of the data, I was not able to take into account rich details of people's life that may influence their institutionally embedded experiences. For example, some individuals might have dual nationalities, parents of different nationalities, etc...(Nielsen \& Nielsen, 2013). Third, given the international nature of the sample and my use of secondary data, I was not able to identify the national origin of 83 CEOs (out 
of 376 successions identified from 2005 to 2010), constituting a $22 \%$ sample size reduction.

In addition to addressing these limitations, future research could explore additional questions regarding the appointment of foreign-born CEOs. For example, a vast area of research building on upper echelon theory (Hambrick \& Mason, 1994) has addressed the impact of executive experiences on organizational outcomes (see Finkelstein et al., 2009 for a review). Future studies could therefore seek to explore the following questions: what is the strategic impact of their appointment? Do they pursue more risky internationalization strategy compared to country nationals? Second, it might be fruitful to select a few cases of foreign-born CEOs and employ qualitative analysis to understand the profound impact of their background on their management style and philosophy. Qualitative analysis could also help examine the complex nature of CEOs' life experiences. For example, if we take the case of Carlos Ghosn (CEO of RenauldNissan), although he was born and raised in Brazil, he is French and the "offspring of a Lebanese father and a French mother, and he speaks six languages including Arabic and now some Japanese" (Birkinshaw et al., 2011, p. 574). Considering such nuances could deepen our understanding of the institutionally embedded knowledge and abilities that CEOs bring to the table. 


\section{REFERENCES}

Allen, M. P., Panian, S. K., \& Lotz, R. E. (1979). Managerial succession and organizational performance: A recalcitrant problem revisited. Administrative Science Quarterly, 24(2), 167-180.

Bailey, E. E., \& Helfat, C. E. (2003). External management succession, human capital, and firm performance: An integrative analysis. Managerial and Decision Economics, 24(4), 347-369.

Barkema, H. G., \& Vermeulen, F. (1998). International expansion through start-up or acquisition: A learning perspective. Academy of Management Journal, 41(1), 7-26.

Barney, J. (1991). Firm resources and sustained competitive advantage. Journal of Management, 17(1), 99-120.

Bigley, G. A., \& Wiersema, M. F. (2002). New CEOs and corporate strategic refocusing: How experience as heir apparent influences the use of power. Administrative Science Quarterly, 47(4), 707-727.

Birkinshaw, J., Brannen, M. Y., \& Tung, R. L. (2011). From a distance and generalizable to up close and grounded: Reclaiming a place for qualitative methods in international business research. Journal of International Business Studies, 42(5), 573-581.

Boeker, W. (1992). Power and managerial dismissal: Scapegoating at the top. Administrative Science Quarterly, 37(3), 400-421.

Boeker, W., \& Goodstein, J. (1993). Performance and successor choice: The moderating effects of governance and ownership. Academy of Management Journal, 36(1), 172-186.

Brannen, M. Y. (2004). When Mickey loses face: Recontextualization, semantic fit, and the semiotics of foreignness. Academy of Management Review, 29(4), 593-616.

Brannen, M. Y., \& Thomas, D. C. (2010). Bicultural individuals in organizations implications and opportunity. International Journal of Cross Cultural Management, 10(1), 5-16.

Caligiuri, P., \& Di Santo, V. (2001). Global competence: What is it, and can it be developed through global assignments? Human Resource Planning, 24(3), 27-35.

Cannella, A. A., \& Lubatkin, M. (1993). Succession as a sociopolitical process: Internal impediments to outsider selection. Academy of Management Journal, 36(4), 763-793. 
Carpenter, M. A. (2002). The implications of strategy and social context for the relationship between top management team heterogeneity and firm performance. Strategic Management Journal, 23(3), 275-284.

Carpenter, M. A., Sanders, W. G., \& Gregersen, H. B. (2001). Bundling human capital with organizational context: The impact of international assignment experience on multinational firm performance and CEO pay. Academy of Management Journal, 44(3), 493-511.

Castanias, R. P., \& Helfat, C. E. (1991). Managerial resources and rents. Journal of Management, 17(1), 155-171.

Castanias, R. P., \& Helfat, C. E. (2001). The managerial rents model: Theory and empirical analysis. Journal of Management, 27(6), 661-678.

Chacar, A. S., Newburry, W., \& Vissa, B. (2010). Bringing institutions into performance persistence research: Exploring the impact of product, financial, and labor market institutions. Journal of International Business Studies, 41(7), 1119-1140.

Chan Kim, W., Hwang, P., \& Burgers, W. P. (1989). Global diversification strategy and corporate profit performance. Strategic Management Journal, 10(1), 45-57.

Chatterjee, S., \& Wernerfelt, B. (1991). The link between resources and type of diversification: Theory and evidence. Strategic Management Journal, 12(1), 33-48.

Chung, C., \& Luo, X. R. (2013). Leadership succession and firm performance in an emerging economy: Successor origin, relational embeddedness, and legitimacy. Strategic Management Journal, 34(3), 338-357.

Contractor, F. J., Kundu, S. K., \& Hsu, C. (2003). A three-stage theory of international expansion: The link between multinationality and performance in the service sector. Journal of International Business Studies, 34(1), 5-18.

Crossland, C., \& Hambrick, D. C. (2007). How national systems differ in their constraints on corporate executives: A study of CEO effects in three countries. Strategic Management Journal, 28(8), 767-789.

Crossland, C., \& Hambrick, D. C. (2011). Differences in managerial discretion across countries: How nation-level institutions affect the degree to which CEOs matter. Strategic Management Journal, 32(8), 797-819.

Cuervo-Cazurra, A., \& Genc, M. (2008). Transforming disadvantages into advantages: Developing-country MNEs in the least developed countries. Journal of International Business Studies, 39(6), 957-979. 
Dahlin, K. B., Weingart, L. R., \& Hinds, P. J. (2005). Team diversity and information use. Academy of Management Journal, 48(6), 1107-1123.

Daily, C. M., Certo, S. T., \& Dalton, D. R. (2000). International experience in the executive suite: The path to prosperity? Strategic Management Journal, 21(4), 515-523.

Dalton, D. R., \& Kesner, I. F. (1985). Organizational performance as an antecedent of inside/outside chief executive succession: An empirical assessment. Academy of Management Journal, 28(4), 749-762.

Datta, D. K., \& Guthrie, J. P. (1994). Executive succession: Organizational antecedents of CEO characteristics. Strategic Management Journal, 15(7), 569-577.

Drazin, R., \& Kazanjian, R. K. (1993). Applying the del technique to the analysis of cross-classification data: A test of CEO succession and top management team development. Academy of Management Journal, 36(6), 1374-1399.

Duvander, A. E. (2001). Do country-specific skills lead to improved labor market positions? An analysis of unemployment and labor market returns to education among immigrants in sweden. Work and Occupations, 28(2), 210-233.

Finkelstein, S., Hambrick, D. C., \& Cannella, A. A. (1996). Strategic leadership West St. Paul, Minn.

Finkelstein, S., Hambrick, D. C., \& Cannella, A. A. (2009). Strategic leadership: Theory and research on executives, top management teams, and boards Oxford University Press, USA.

Fligstein, N. (1987). The intraorganizational power struggle: Rise of finance personnel to top leadership in large corporations, 1919-1979. American sociological review, 44-58.

Geletkanycz, M. A. (1997). The salience of 'culture's consequences': The effects of cultural values on top executive commitment to the status quo. Strategic Management Journal, 18(8), 615-634.

Geringer, J. M., Beamish, P. W., \& daCosta, R. C. (1989). Diversification strategy and internationalization: Implications for MNE performance. Strategic Management Journal, 10(2), 109-119.

Giambatista, R. C., Rowe, W. G., \& Riaz, S. (2005). Nothing succeeds like succession: A critical review of leader succession literature since 1994. The Leadership Quarterly, 16(6), 963-991.

Grusky, O. (1963). Managerial succession and organizational effectiveness. American Journal of Sociology, 69(1), 21-31. 
Gupta, A. K. (1984). Contingency linkages between strategy and general manager characteristics: A conceptual examination. Academy of Management Review, 9, 399-412.

Hambrick, D. C., Davison, S. C., Snell, S. A., \& Snow, C. C. (1998). When groups consist of multiple nationalities: Towards a new understanding of the implications. Organization Studies, 19(2), 181-205.

Hambrick, D. C., \& Mason, P.A. (1984). Upper echelons: the organization as a reflection of its top managers. Academy of Management Review, 9(2), 193-206.

Hannan, M. T., \& Freeman, J. (1984). Structural inertia and organizational change. American Sociological Review, 49(2) , 149-164.

Hitt, M. A., Hoskisson, R. E., \& Ireland, R. D. (1994). A mid-range theory of the interactive effects of international and product diversification on innovation and performance. Journal of Management, 20(2), 297-326.

Hitt, M. A., Hoskisson, R. E., \& Kim, H. (1997). International diversification: Effects on innovation and firm performance in product-diversified firms. Academy of Management Journal, 40(4) , 767-798.

Hofstede, G., \& Hofstede, G. J. (2005). Cultures and organizations, software of the mind, intercultural cooperation and its importance for survival. McGraw-Hill: New York.

Jacquemin, A. P., \& Berry, C. H. (1979). Entropy measure of diversification and corporate growth. The Journal of Industrial Economics, 27(4), 359-369.

Kesner, I. F., \& Sebora, T. C. (1994). Executive succession: past, present \& future. Journal of Management, 20(2), 327-372.

Kim, W. K., Hwang, P., \& Burgers, W. P. (1989). Global diversification strategy and corporate profit performance. Strategic management journal, 10(1), 45-57.

Kleinbaum, D.G., Kupper, L.L., \& Muller, K.E. (1988). Applied Regression Analysis and Other Multivariable Methods. PWS Publishing: Boston, MA.

Kostova, T. (1997). Country institutional profiles: Concept and measurement. Academy of Management Proceedings, 1997(1), 180-184.

LaFromboise, T., Coleman, H. L., \& Gerton, J. (1993). Psychological impact of biculturalism: evidence and theory. Psychological bulletin, 114(3), 395.

Levy, O., Beechler, S., Taylor, S., \& Boyacigiller, N. A. (2007). What we talk about when we talk about 'global mindset': Managerial cognition in multinational corporations. Journal of International Business Studies, 38(2), 231-258. 
Li, J., \& Canella, A. (2003). Executive job change in technology-based start-ups: Knowledge integration in an inherently political setting. Paper presented at the Academy of Management, Seattle, WA.

Magnusson, P., \& Boggs, D. J. (2006). International experience and CEO selection: An empirical study. Journal of International Management, 12(1), 107-125.

Nadkarni, S., Herrmann, P., \& Perez, P. D. (2011). Domestic mindsets and early international performance: The moderating effect of global industry conditions. Strategic Management Journal, 32(5), 510-531.

New York Times. (2007a). Troubled Citigroup Names Pandit as Chief Executive. December 11.

New York Times. (2007b). Foreign-born chiefs reflect Fortune 100's global reach. December 12.

Nguyen, A. M. D., \& Benet-Martínez, V. (2007). Biculturalism unpacked: Components, measurement, individual differences, and outcomes. Social and Personality Psychology Compass, 1(1), 101-114.

Nielsen, B. B., \& Nielsen, S. (2013). Top management team nationality diversity and firm performance: A multilevel study. Strategic Management Journal, 34(3), 373-382.

Nielsen, S., \& Nielsen, B. B. (2010). Why do firms employ foreigners on their top management team? An exploration of strategic fit, human capital and attraction-selectionattrition perspectives. International Journal of Cross Cultural Management, 10(2), 195209.

Ocasio, W., \& Kim, H. (1999). The circulation of corporate control: Selection of functional backgrounds of new CEOs in large US manufacturing firms, 1981-1992. Administrative Science Quarterly, 44(3), 532-562.

Ondrack, D. (1985). International transfers of managers in North American and European MNEs. Journal of International Business Studies, 16(3), 1-19.

Palich, L. E., Cardinal, L. B., \& Miller, C. C. (2000). Curvilinearity in the diversificationperformance linkage: An examination of over three decades of research. Strategic Management Journal, 21(2), 155-174.

Parkhe, A. (1991). International Portfolio Analysis: A New Model, Management International Review, 31(4), 365-379.

Perlmutter, H. (1969). The tortuous evolution of the multinational corporation, Columbia Journal of World Business, 4(1): 9-18. 
Pfeffer, J. S., \& Salancik, G.GR (1978). The external control of organizations: A resource dependence perspective. Harper \& Row: New York.

Ramaswamy, K., \& Li, M. (2001). Foreign investors, foreign directors and corporate diversification: An empirical examination of large manufacturing companies in India. Asia Pacific Journal of Management, 18(2), 207.

Ronen, S., \& Shenkar, O. (1985). Clustering countries on attitudinal dimensions: A review and synthesis. Academy of Management Review, 10(3), 435-454.

Sambharya, R. B. (1996). Foreign experience of top management teams and international diversification strategies of US multinational corporations. Strategic Management Journal, 17(9), 739-746.

Sanders, W. G., \& Carpenter, M. A. (1998). Internationalization and firm governance: The roles of CEO compensation, top team composition, and board structure. Academy of Management Journal, 41(2), 158-178.

Sellers, L. J., "Lilly's International Family: Sidney Taurel Takes His Global Team Beyond Prozac," Pharmaceutical Executive , March 1, 2001, p. 40.

Shen, W., \& Cannella, A. A. (2002). Revisiting the performance consequences of CEO succession: The impacts of successor type, postsuccession senior executive turnover, and departing CEO tenure. Academy of Management Journal, 45(4), 717-733.

Snow, C. C., \& Hrebiniak, L. G. (1980). Strategy, distinctive competence, and organizational performance. Administrative Science Quarterly, 25(2), 317-336.

Song, J. H. (1982). Diversification strategies and the experience of top executives of large firms. Strategic Management Journal, 3(4), 377-380.

Tihanyi, L., Griffith, D. A., \& Russell, C. J. (2005). The effect of cultural distance on entry mode choice, international diversification, and MNE performance: A meta-analysis. Journal of International Business Studies, 36(3), 270-283.

Vancil, R. F. (1987). Passing the baton: Managing the process of CEO succession. Harvard Business School Press: Boston, MA.

Von Glinow, M. A., Shapiro, D. L., \& Brett, J. M. (2004). Can we talk, and should we? Managing emotional conflict in multicultural teams. Academy of Management review, $29(4), 578-592$.

Wiersema, M. F., \& Bowen, H. P. (2008). Foreign-based competition and corporate diversification strategy. Strategic Management Journal, 26(12), 1153-1171. 
Zajac, E. J., \& Westphal, J. D. (1996). Who shall succeed? how CEO/board preferences and power affect the choice of new CEOs. Academy of Management Journal, 39(1), 6490 .

Zhang, Y., \& Rajagopalan, N. (2003). Explaining new CEO origin: Firm versus industry antecedents. Academy of Management Journal, 46(3), 327-338.

Zhang, Y., \& Rajagopalan, N. (2004). When the known devil is better than an unknown god: An empirical study of the antecedents and consequences of relay CEO successions. Academy of Management Journal, 47(4), 483-500.

Zhang, Y., \& Rajagopalan, N. (2010). Once an outsider, always an outsider? CEO origin, strategic change, and firm performance. Strategic Management Journal, 31(3), 334-346.

Zhou, M. (1997). Growing up American: The challenge confronting immigrant children and children of immigrants. Annual Review of Sociology, 23, 63-95. 


\title{
Foreign-Born CEO Successions and Changes in M\&A Strategy
}

\author{
ABSTRACT \\ While extant research suggests that CEOs' company and industry origins may \\ shape their strategic actions, little is known about CEOs' country of origin and its \\ strategic implications. In this paper, I build on this research and explore the link between \\ foreign CEO successions and changes related to firms' $M \& A$ strategy. I argue that \\ foreign-born CEOs are likely to possess skills and knowledge related to foreign \\ institutional environments and have a mindset less focused on firms' domestic \\ environments. Such skills and mindset may give foreign CEOs greater confidence and an \\ edge to engage in foreign expansions. Using a sample of 261 CEO successions taken \\ place in the largest companies around the world from 2005 to 2010, I find that foreign- \\ born CEOs are likely to initiate more changes in firms' international M\&A strategy than \\ their national counterparts. Additionally, I show the moderating role of new CEOs' \\ insiderness; new CEOs with firm-specific skills are more likely to alter firms' \\ international M\&A strategy than CEOs with a low level of firm-specific skills.
}

\section{INTRODUCTION}

What are the strategic implications of changing a company's chief executive officer (CEO)? Much of the popular press presumes that there is a link between CEO origin and strategy and suggests that boards of directors change CEOs when radical changes in firm strategy are needed (NYT, 2005; The Economist, 2012). This interest in 
CEO successions and their strategic and performance benefits has also been mirrored in scholarly research. For example, management theorists have paid considerable attention to examining successor origin - be it external or internal to the firm, or external or internal to its industry - and its impact on firm outcomes (e.g., Chen \& Hambrick, 2012; Chung \& Luo, 2013; Karaevli, 2007; Miller, 1993; Wiersema, 1992; Zhang \& Rajagopalan, 2010a).

Alongside the current successor types researched in the literature, I note in this study that successors' country of origin may also have a significant bearing on firm strategy. Considering the growing number of foreign-born CEO appointments (Forbes, 2009; NYT, 2007; WSJ, 2004), it may be important to examine the strategic implications of foreign-born CEO successions. By foreign-born and non-native CEOs, I mean individuals who were born and spent their formative years ${ }^{4}$ in a country other than their firm's country of origin (Hambrick, Davidson, \& Snell, 1998; Nielsen \& Nielsen, 2013).

Based on prior research (e.g., Geletkanycz, 1997; Hambrick et al., 1998; Nielsen $\&$ Nielsen, 2013), I argue that the institutional environment in which an executive is reared may have an imprinting effect that may shape this person's knowledge and skill set and mindset (Geletkanycz, 1997). Chief executives' abilities and mindsets, shaped in part by their national origin (in addition to other factors) are likely to influence firm strategy. Ultimately, foreign-born CEOs' skills and mindsets could lead them to follow different strategies from their native-born counterparts.

I focus more specifically on mergers and acquisitions (M\&A), which have been identified to serve as an important conduit for firms to change, reconfigure, and/or

\footnotetext{
${ }^{4}$ Formative years refer to the experience of an individual from his/her birth to when he/she reaches 17.
} 
redeploy their capabilities (Barkema, Baum, \& Mannix, 2002; Capron, Dussauge, \& Mitchell, 1998). I propose that foreign-born CEOs with their mindsets partly defined by their national origin and by their experience living in their firm's home country may be more attuned to pursue international opportunities (Geletkanycz, 1997). Hence, foreignborn CEOs may instigate more changes in firms' cross-border acquisition strategy than their native counterparts. Following this same logic, native CEOs should be more engaged in domestic mergers and acquisitions.

Second, I theorize on the moderating influence of CEOs' company of origin by exploring CEOs' insiderness. I expect foreign CEOs who are internally appointed and have significant firm-specific experience to be able to exert more changes in firms' crossborder M\&As. Indeed, like any externally appointed CEOs, outside foreign-born CEOs (in contrast with insiders) lack firm-specific skills and support from key stakeholders (Harris \& Helfat, 1997; Karaevli, 2007; Shen \& Canella, 2002; Zhang \& Rajagopalan, 2004). This would in turn constrain their ability to take new strategic actions since they may be disadvantaged by their limited knowledge of firms' internal environment and by their lack of ties with key organizational members. I argue that prior experience within the firm could help mitigate some of these disadvantages. In addition, such prior experience could help reduce additional obstacles that foreign CEOs may face. For example, foreign CEO successions may be associated with some degree of cultural misfit since foreign CEOs' cultural heritage may differ significantly from that of key organizational members (The Huffington Post, 2012).

In a similar vein, I propose that national CEOs could also be constrained by their degree of insiderness. While externally-appointed national CEOs may not face the exact 
same challenges as the ones noted above (e.g., cultural misfit), they are likely to experience similar obstacles. For example, their strategic actions could be considerably impacted by their lack of firm-specific skills and knowledge of firms' competitive environments. I therefore expect new CEO insiderness to moderate the relationship between national successions and changes in domestic M\&As.

The hypotheses developed in this paper were tested using a dataset of new CEO appointments made by public companies that were part of the Global 500 ranking between the years 2005 and 2010. The ultimate sample consisted of 261 CEO appointments, including 58 foreign successions in 234 unique firms originating from 27 countries. After controlling for firm, industry, and CEO factors, I find support for the theoretical premise of this research that foreign successions do impact firms' strategic expansion as it relates to patterns of mergers and acquisitions.

Surveying foreign CEO successions and their strategic outcomes offers the following contributions. First, it advances CEO succession research by elucidating the importance of new CEOs' national origin for firms' strategic expansion. While a great deal of research has focused on the industry and firm origins of new CEOs, the make-up of the executive suite is changing. This paper shows that the internationalization of the executive labor market has some important strategic implications.

Second, this study complements previous research on CEOs' international experience (e.g., Carpenter, Sanders, \& Gregersen, 2001; Daily, Certo, \& Dalton, 2000; Sambharya, 1996; Takeuchi, Tesluk, Yun, \& Lepak, 2005) by proposing another dimension of executive profile that affects CEO strategies. Finally, by investigating the impact of CEO profile on mergers and acquisitions, this study complements the vast 
literature on the consequences of CEO succession, which until now has mostly focused on outcomes such as changes in firms' product diversification strategy (e.g., Wiersema \& Bantel, 1992), corporate strategic refocusing (e.g., Bigley \& Wiersema, 2002), or firm performance (Karaevli, 2007; Shen \& Canella, 2002).

The rest of this paper is organized as follows. I first review CEO succession research by taking stock of studies surveying the impact of different types of successions. Second, I develop hypotheses surrounding the influence of non-national successions on firms' strategic expansion and the moderating role of successors' company of origin. Third, I elaborate on my research design and describe the sample and the key constructs used in this research. Fourth, I describe my empirical results. Finally, I discuss my findings and provide some concluding remarks.

\section{TYPES OF SUCCESIONS AND THEIR STRATEGIC IMPACT}

CEOs have been identified to be major architects of corporate strategy and catalysts of change (Bigley \& Wiersema, 2002; Child, 1972). Prior research has discussed the strategic implications of various types of CEO successions and the benefits associated with CEO successions. The general premise of this research is that when successions occur, new CEOs with new skills, abilities, and perspectives take charge of an organization (Boeker, 1997). These new CEOs will most likely draw on their existing competencies and skills to make strategic decisions and initiate new strategic actions (Finkelstein, Hambrick, \& Cannela, 2009). The main types of successions studied in prior literature, and reviewed briefly below, include intra-firm versus outside-firm successions (or inside versus outside successions) and their extensions. Another strand of 
research has focused on intra-industry and outside-industry successions and their implications.

Intra-firm versus outside-firm successions and extensions. Inspired by the work of Grusky (1964) and Carlson (1961), an important volume of research has explored the implications of opting for an inside versus an outside CEO succession (e.g., Canella \& Lubatkin, 1993; Chung \& Luo, 2013; Giambatista, Rowe, \& Riaz, 2005; Shen \& Canella, 2002; Wiersema, 2002). It is often argued that inside successors bring firm-specific skills to the forefront. Firm-specific skills could be defined as "tacit knowledge about unique routines and procedures, corporate culture and informal norms, and experience with specific management systems and processes" (Groysberg, McLean, \& Norhia, 2006, p. 6). These skills involve "an in-depth understanding of factors such as a company's history, culture, and internal strengths and weaknesses" (Harris \& Helfat, 1997, p. 896).

A general theme in this literature is that an outsider is more likely to implement radical strategic change (Helfat \& Baily, 2005). Extant CEO succession research often equates outside successions to organizational change that further leads to better performance (Zhang \& Rajagopalan, 2010b). Outside successors are also more likely after their appointment to bring in new executives, revamp firms' top management teams, and dismiss incumbent managers (Karaevli, 2007; Shen \& Canella, 2002).

Some examples of research focusing on strategic change include the study by Tushman, Virany, and Romanelli (1985), which showed that external successions were positively associated with initiation of strategic reorientation. In a similar vein, Wiersema (1992) proposed and demonstrated that outsiders were more likely to engage in postsuccession product diversification than insiders. 
Many scholars have also sought to extend the realm of this research to include other salient dimensions of successor origin (Karaevli, 2007). For examples, going beyond the strict internal vs. external differentiation, Wiersema (1995) explored nonroutine and routine successions ${ }^{5}$ and their influence on organizational restructuring. Bigley and Wiersema (2002) discussed the importance of considering heir apparent experience when theorizing about the impact of insiders on strategic change. Their argument lies in the idea that not all inside appointments are created equal. Heir apparent experience could provide a significant edge to insiders since heir apparent executives derive significant benefits from on-the-job training and their firm-specific skills, referred to in this literature as their familiarity with firms' internal context (Ocasio, 1999; Zhang \& Rajagopalan, 2004).

Another study highlighting firm-specific skills was conducted by Zhang and Rajagopalan (2004); the authors made a distinction between relay successions, non-relay successions, and outside successions and theorized about the impact of each type of successions. They showed that relay successions were associated with a lower risk of mismatch between new CEOs and their new firms which in turn positively affects firm performance. Similarly, Shen and Canella (2002) examined the performance implications of hiring different types of CEO successors: contenders, followers, and outsiders. These authors found that the senior executive turnover following a contender succession had a positive effect on firm performance. They argue that contenders given their familiarity with the existing cadre of executives and their firm-specific skills might be in a favorable

\footnotetext{
${ }^{5}$ A routine succession occurs when an executive departs due to retirement.
} 
position to replace executives and identify executives that could help them accomplish the needed strategic change.

Outside-industry versus intra-industry successions. Others studies have brought to the forefront the salience of CEO's industry of origin distinguishing between intra and outside industry successors (Harris \& Helfat, 1997; Zhang \& Rajagopalan, 2003). Intraindustry successors are likely to possess industry-specific skills or the "technical, regulatory, customer, or supplier knowledge unique to an industry" (Groysberg et al., 2006, p. 3). "Intra-industry successors have industry-specific knowledge that may be readily transferable to firms in the same industry" (Zhang \& Rajagopalan, 2003, p. 327). For example, a CEO leading a firm operating under the rules of the U.S. Food and Drug Administration may develop different industry-specific skills vis-à-vis a CEO managing a firm that has to comply with the rules of the Federal Energy Regulatory Commission (Groysberg et al., 2006).

Consequently, opting for an outside or an intra-industry succession may have important organizational implications. Zhang and Rajagopalan (2003) assert that hiring external CEOs from the same industry is likely to increase the chance of learning from the strategies and practices of competitors in the same industry. On the other hand, hiring an outside industry successor may be favored if the firm seeks a change from "industry recipes" (Spender, 1989). For example, Marvin Miller, who came from the steel industry, with its heavily militant union, transformed the strategies and practices of the baseball players' association by transplanting some of the same techniques he had learned from managing a steel company (Chacar \& Hesterly, 2008). In a related study, Chen and Hambrick (2012) showed that troubled firms operating in a struggling industry will 
benefit from having a new $\mathrm{CEO}$ who is an industry outsider. According to the authors, "such an executive provides fresh perspective, new knowledge, and new perspective to facilitate the requisite departure from industry recipes" (Chen \& Hambrick, 2012, p. 229).

More recently, the interest in the firm and industry of origin of the CEO in succession research seems to be waning; interest has shifted more generally on examining the relationship between CEO profiles in general and strategic actions and firm performance (Lewis, Walls, \& Dowell, 2013; Luo, Kanuri, \& Andrews, 2013) and on exploring other factors influencing CEOs' actions (Quigley \& Hambrick, 2012; Westphal \& Deephouse, 2011). However, as I stated earlier, an important aspect of new CEO origin, his/her nationality, has never been examined before despite its importance as argued below.

\section{HYPOTHESES DEVELOPMENT}

While CEO succession research has shown that CEOs' origin and experiences confer them skills and abilities that have important strategic ramifications, we do not know much about the implications of foreign successions. In the subsequent sections, I discuss an additional facet of CEO origin, namely country of origin, and its importance for firms' strategic expansion. I also theorize on its interplay with CEOs' company of origin or degree of insiderness arguing that a match between a firm's nationality and its CEO's origin, or the lack thereof, will drive its mergers and acquisitions strategy.

More specifically, I hypothesize that given that their skills and mindsets are likely to be less related to firms' domestic environment, foreign-born CEOs are likely to initiate more changes in firms' cross-border M\&A strategy than their national counterparts. 
Alternatively, I expect national CEOs to engage in more changes related domestic M\&As. Finally, I consider the moderating influence of CEOs' company of origin contending that foreign insiders may be better positioned to initiate changes in firms' international expansion. Figure 2 provides a summary of the hypotheses on which I elaborate below.

Figure 2: Conceptual Model

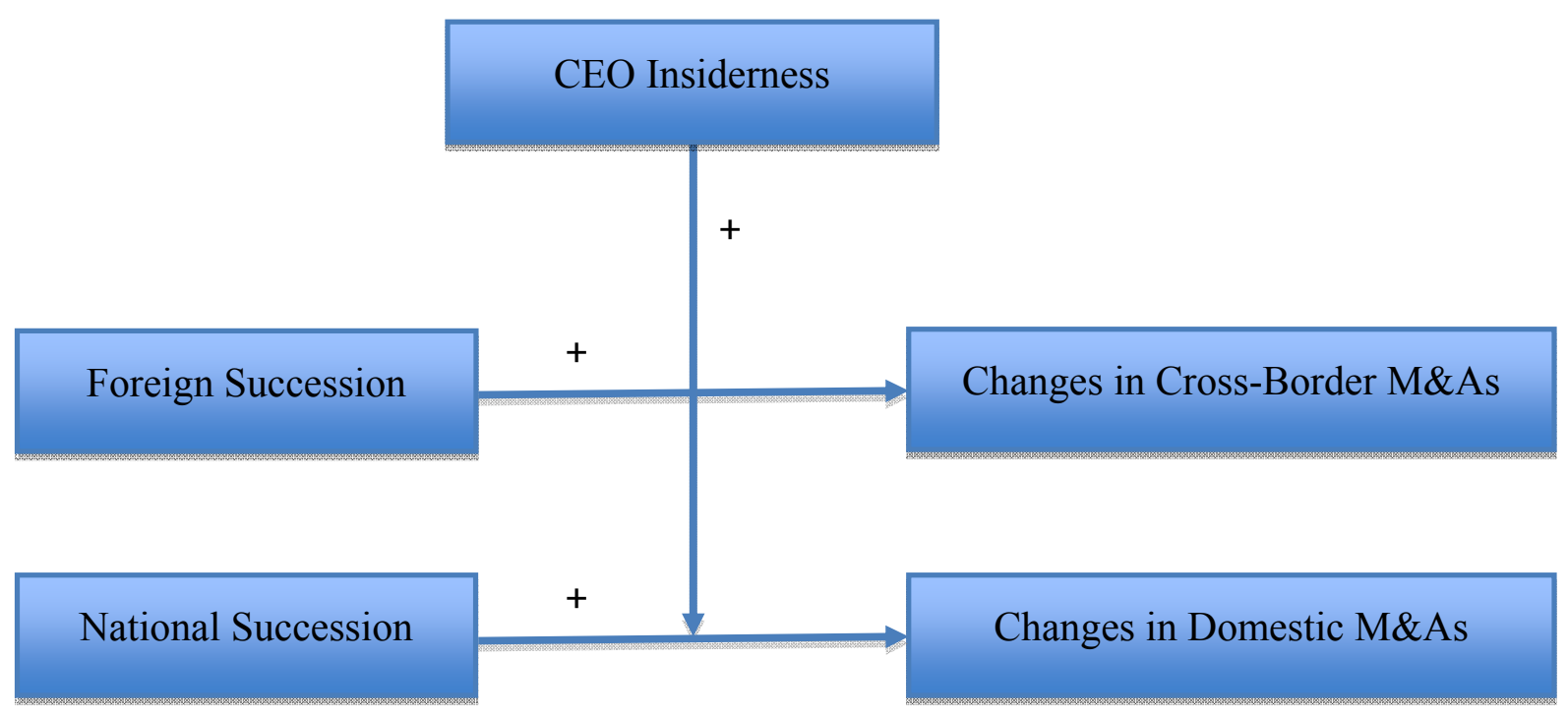

\section{Foreign successions and changes in M\&As}

As noted above, current research has explored successors' industry and company origins and the skills that they may embody, namely firm-specific skills when considering intra-firm versus outside-firm successions, and industry-specific skills surveying intra-industry and outside-industry successions. A third type of skills that may be important to consider is country-specific skills. Country-specific skills (CSS) to managers' knowledge and abilities that are applicable and specific to a particular national 
institutional context. CSS could also include language (Duvander, 2001) and expertise in dealing and building relationships with suppliers, customers, regulators, and other key stakeholders in a particular country.

Not only country-specific skills may influence the preference of firms for national CEOs versus foreign-born CEOs, but also they are likely to impact the strategic path that a CEO takes. I argue here that CSS could play a significant role in shaping firms' expansion choices. First, foreign CEOs may have CSS that relate to another country environment from firms' home country. Having CSS related to other institutional environments could help foreign-borns develop a mindset or frame of reference that is less centered on firms' domestic environment. We know that managers' individual experiences shape their mental representations of the world and their cognitive schema (Fiske \& Taylor, 1984; Wiersema, 1992), which in turn influence their strategic-decision making process.

In addition to these CSS, being born and raised in another country is susceptible to affect people's mental representation of the world. Research in psychology has shown that people significantly exposed to at least two cultural systems such as non-nationals are prone to be influenced by dual cultural identities leading them to engage in active cultural frame switching” (Benet-Martinez, Leu, Lee, \& Morris, 2002, p. 493). Cultural frame switching characterizes situations in which people "move between different cultural meaning systems in response to situational cues" (Benet-Martinez et al., 2002, p. 493). It also implies that foreigners may have a strong cultural imprint of a country other than firms' country of origin; they are therefore likely have a mindset or world view less focused on firms' domestic setting than that of their national counterparts. 
I suggest that such mindset would help foreign CEOs to be more attuned to global opportunities than their national counterparts. As argued by Nadkarni and Perez (2007), executives' mindsets influence the alternatives that they consider when making strategic decisions. Since international expansion requires that managers overcome their domestic mindset and domestic myopia (Barkema \& Vermeulen, 1998; Carpenter \& Fredrickson, 2001) and foreign CEOs are likely to have a mindset less entrenched in firms' domestic environment, I expect them to be more predisposed to consider international expansion options as opposed to domestic ones.

In addition to such mindset, new CEOs tend to act according to their going-in mandate or the expectations of board members at the time of their appointment (Finkelstein et al., 2009; Vancil, 1987). Their initial actions tend to reflect this mandate. In the case of a foreign succession, board members are likely to expect the new CEO to make important changes related to companies' international activities. For example, a UK-based executive recruiter recounted that there is a growing demand in the executive labor market for non-national top executives to globalize companies $(F T, 2012)$. Hence, one could expect foreign CEOs to have a significant penchant toward international expansions to fulfill such expectations $(F T, 2012)$. In order to sustain such internationalization efforts, they are likely to hire other foreigners in the corporate suite.

Conversely, since national CEOs are more likely to hold skills and institutional knowledge that for the most relate to firms' home country, they may possess an advantage related to their perception of firms' domestic opportunities. They may therefore be more inclined to grow firms domestically since they might perceive foreign risks as greater. 
The above arguments led me to propose the following hypotheses:

Hypothesis 1. A foreign CEO is likely to initiate more changes in cross-border $M \&$ As than a national $C E O$.

Hypothesis 2. A national CEO is likely to initiate more changes in domestic M\&As than a foreign CEO.

\section{The moderating influence of CEO's insiderness}

Earlier, I proposed that foreign-born CEOs are likely to engage in more changes related to firms' international M\&As than their national counterparts. In the following section, I discuss the extent to which such relationship may be contingent upon new CEOs' insiderness. While most research has dichotomized CEOs' company of origin, recent research has discussed the need to consider different degrees of insiderness (Finkelstein et al., 2009; Karaevli, 2007). The idea is that a new CEO who has been working for a firm two years at the time of his/her appointment is a different type of insider vis-à-vis an individual who has spent twenty-five years within a firm (Finkelstein et al., 2009). Finkelstein and colleagues (2009) observe that the former individual could be considered an outsider compared to the CEO with twenty-five years of tenure.

As highlighted above, insiderness and outsiderness are thought to confer CEOs different skills and abilities and are likely to shape their strategic actions. While outsiders are considered more equipped to bring a new and fresh perspective to the organization and initiative important strategic changes (Finkelstein et al., 2009; Kesner \& Sebora, 1994), extant research has emphasized significant disadvantages to new CEOs' outsiderness, which could significantly reduce its benefits (e.g., Karaevli, 2007). First, as 
Karaevli (2007) observed, "as a new CEO's outsiderness increases, it is more likely that he or she will lack critical firm- and industry-specific skills" to make important strategic decisions (688). Second, there is an important risk that a new outsider does not fit well with the culture and the strategic demands of the organization (Karaevli, 2007). Third, there is a strong likelihood that current TMT members will leave the firm; the members who stay are likely to have a negative attitude toward the new appointee (Shen \& Cannella, 2002).

In the case of foreign successions, it may be expected that the appointment of a foreign-born individual could engender some additional challenges or even some frictions in some cases $(F T, 2012)$. First, there might be some uncertainty regarding the ability of a foreigner to fit the national culture of firms' home country $(N Y T, 2007)$. A foreign CEO succession could be associated with cultural problems since foreign CEOs' culture may be different from that of other key organizational members (i.e., board members and TMT members), which might lead to cultural clashes. Second, while in any succession event there is always a possibility of a misfit between the CEO and the organization (Karaevli, 2007; Zhang \& Rajagopalan, 2003), such potential misfit might be exacerbated in the case of a foreign CEO succession given the additional complexity inherent in the diversity that a non-national brings to the corporate suite. Also, there might be some language problems since foreign CEOs may not have the same native language as the language spoken in the country in which they lead.

To illustrate the idea of misfit, one could point out several examples. Recently, the CEO of the Japanese company Olympus, Michael Woodford (a British national), was dismissed because of his lack of understanding of the company's management and the 
Japanese culture (The Huffington Post, 2012). Another example relates to Sol Trujillo, the ex American-born CEO of the Australian firm Telstra. Sol Trujillo claimed to have experienced a great deal of racism during his tenure at Testra and have suffered from the lack of diversity that exists within the company (ABC News, 2009).

I argue that such factors could be less pronounced in the case of an inside foreign succession. Tenure within the organization may have granted foreign CEOs the opportunity to build firm-specific skills and knowledge that could facilitate the initiation of new strategies. Also, he/she may have had the chance to acquire significant knowledge about a firm's organizational culture and its national heritage (Bartlett \& Ghoshal, 1989); such knowledge could be instrumental to interact with important internal and external stakeholders and obtain their support. Second, their potential social ties to organizational members and stakeholders could help them mitigate some of the important challenges that new CEOs face when joining the executive suite (Finkelstein et al., 2009). Finally, the potential misfit and cultural frictions noted earlier could be reduced since the board in the case of an inside succession could better assess the suitability of an internal candidate for the post. We know that the risk of adverse selection is lower in the case of inside successions.

Hence, I propose the following hypothesis:

Hypothesis 3. The effect a foreign-born CEO on changes in cross-border M\&As is greater when he or she has a higher level of insiderness.

In addition to exerting an influence on foreign CEOs' ability to initiate changes, insiderness may also impact national CEOs' capacity to alter firms' domestic M\&As strategy. While national CEOs that are externally appointed may not be subject to the 
cultural frictions described above, their capacity to initiate strategic actions could nevertheless be influenced by their lack of firm-specific skills and social ties with key firms' constituents. I therefore expect insiderness to be positively related to national CEOs' ability to institute changes in firms' domestic M\&A strategy. Hence, I propose:

Hypothesis 4. The effect a national CEO on changes in domestic M\&As is greater when he or she has a higher level of insiderness.

\section{METHODS}

The population for this study is all firms listed on the Global 500 ranking from 2005 to 2010 resulting in a total of 689 unique firms from 36 countries. After deleting privately held firms, state-owned companies, and subsidiaries of other firms, a total of 533 firms remained. I identified $376 \mathrm{CEO}$ successions occurring within these firms. CEO names were primarily obtained using the Global 500 database. Missing names were collected using various sources such as the Directory of Corporate Affiliations, Corporate Library (for US firms), Hoovers, companies' annual reports, and 20F.

Data on CEOs' profiles and appointment dates were collected primarily via content-analyzing biographies derived from a variety of sources such as the Directory of Corporate Affiliations, company's annual reports and 20F, companies' website, Lexis Nexis, Business Week Executive Profile, Hoovers, Who's Who in Business and Finance, and Bloomberg. Using such data sources, I could find complete information on the characteristics of 293 CEOs. 
Following prior succession research, I eliminated all CEO successions in which the CEO's tenure was two years or less. I then obtained a sample of 285 successions. Firm and industry level variables were collected via SDC Platinum (a Thomson Reuters database), Bloomberg, Capital IQ (a Standard and Poor's database), company's annual reports and 20F. After combining firm-level and industry-level variables, the final sample is composed of $261 \mathrm{CEO}$ successions occurring in 234 companies (implanted in 27 countries). 208 firms had one succession and 26 companies experienced two successions.

\section{Measures}

\section{Criterion Variables}

Change in Cross-Border M\&As. This variable is measured as follows. I first calculated the change between the number of cross-border M\&As pre-succession and post succession. The measure could depicted by the following equation:

$\left[\left({\text { cross-border } M \& A s_{t+1}}+\right.\right.$ cross-border $\left.\left.M \& \mathrm{As}_{\mathrm{t}+2}\right) / 2\right]$ - cross-border $\mathrm{M} \& \mathrm{As} \mathrm{t}_{\mathrm{t}-1}$

Second, I took the absolute value of this change and standardized the absolute value (mean $=0$, standard deviation=1) (Zhang \& Rajagopalan, 2010a). The selection of a two-year post-succession period was chosen since previous succession research indicates that most strategic actions taken by CEOs occur in the first two years in office (Gabarro, 1987; Shen \& Canella, 2002; Vancil, 1987). This variable was obtained using Thomson Financial Securities Data Worldwide M\&A database (also called SDC platinum). This database includes a comprehensive record of all M\&As that were completed on a worldwide basis (Dikova, Sahib, \& van Witteloostuijn, 2009). SDC platinum data were compiled using a number of different sources including foreign and US newspapers, SEC 
statements and records, records obtained from comparable institutions in foreign countries, and various other outlets (Dikova et al., 2009). SDC provides data on the geographical location of the target and acquiring firms that helped identify cross-border deals.

Changes in Domestic $M \& A s$. This variable is measured in the same way as the previous construct, change in cross-border M\&As. Instead of considering cross-border deals however, I used mergers and acquisitions completed in firms' home country.

\section{Explanatory Variable and Moderator}

Foreign/National Succession. This is a dummy variable taking a value of 1 if the CEO was born and raised in a country other than his/her firm's country of origin and 0 otherwise (Hambrick et al., 1998). A value of 1 indicates a foreign succession and a value of 0 refers to a national succession. Information on CEO nationality and formative years was collected via several sources including Hoovers, company's annual reports and 20F, Bloomberg, Lexis Nexis, and Who is Who in Business and Finance, and a 1000 CEOs.

The geographical implantation of firms' headquarter was found in Compustat North America, Compustat Global, Bloomberg, and Capital IQ. Three firms (Unilever, Royal Dutch Shell, and Rio Tinto) had dual headquarters and were assigned to the oldest headquarter' country for convenience. Out of the 261 CEO successions observed, there were 58 foreign-born CEO successions.

New CEOs' Insiderness. This is a continuous variable measured by the number of years that a new CEO worked at a firm at the time of his or her appointment. This measure ranges from 0 (outside CEOs with no experience with the firm) to 47 . To create the interaction term between foreign-born successions and new CEOs' insiderness, I mean- 
centered the moderating variable to address potential multicollinearity issues (Aiken \& West, 1993). Information on CEOs' professional experience was gathered through a number of outlets including Lexis Nexis, Business Week Executive Profile, Hoovers, Who's Who in Business and Finance, Bloomberg, company's annual reports and 20F, and companies' website.

\section{Control Variables}

I introduced in the models a number of control variables to account for the effect of other possible explanatory variables.

In addition to the modeling technique used to control for fixed firm effects, I used the following controls at the firm level. Following prior CEO succession research, I controlled for pre-succession firm size (t-1) as measured by the log of assets since firm size could affect firms' strategic direction (Miller, 1991). Second, I controlled for presuccession firm performance (t-1) as measured by adjusted return on assets (ROA) defined as a focal firm's ROA adjusted by its industry ROA. The third firm level control was free cash flow (t-1) since, in addition to ROA, it could impact firms' financial health and the availability of internal funds that could use to finance their acquisitions (Harford, 1999). This variable is measured by the difference between cash flow from operations and capital expenditures. Data for firm size, adjusted ROA, and free cash flow were collected through Bloomberg. Fourth, since multinationals firms are likely to engage in more cross-border M\&As as opposed to domestic firms, I added a dummy variable to the models taking a value of 1 if a firm derives more than $10 \%$ of its sales abroad and 0 otherwise. Data for firms' foreign sales ratio were obtained through several sources including firms' annual reports and 20F, Capital IQ, and Bloomberg. Fifth, I controlled 
for firm age, as the stage of a firm's life cycle could affect M\&As. Data on firm age were obtained through Bloomberg. Finally, prior number of $M \& A s(\mathrm{t}-1)$ was used as a control since the present study's dependent variable is measuring change in M\&A strategy; change scores are likely to correlated with their initial measurement point (Bergh \& Fairbank, 2002); this control also accounts for a firm's proclivity to rely on mergers and acquisitions in the domestic arena and outside of its country of origin. Prior number of M\&As was found in SDC Platinum.

To account for industry variations, I added two industry controls. The first one relates to firms' level of industry globalization captured by the average foreign sales ratio of each firm's primary industry (measured at the 2-digit SIC level) (Carpenter et al., 2001). Another control is made for industry concentration measured by the four-firm concentration ratio for a company's main Global Industry Classification Standard $\left(\mathrm{GICS}^{6}\right)($ Chacar, Newburry, Vissa, \&, 2010). Data to calculate this ratio were collected using Bloomberg.

At the CEO level, I controlled for international experience captured by a factor composed of CEOs' educational and professional experience outside their home country and their firm's country of origin. The factor is comprised of the following three indicators: 1) educational experience 2) number of years spent abroad 3) number of countries in which an individual worked. These indicators were collected through various sources including Lexis Nexis, Business Week Executive Profile, Hoovers, Who's Who in Business and Finance, the International Directory of Business Biographies, Bloomberg, company's annual reports and 20F, and companies' website.

\footnotetext{
${ }^{6}$ GISC distinguishes 24 industry groups.
} 
Finally, two additional controls were entered in the models. I introduced a year of hire control measured by the year in which a CEO was appointed to account for the potential impact of time variations within the period of study (Zhang \& Rajagopalan, 2003). I also controlled for companies's region of origin using dummy variables. In order to classify companies into regions, I divided the world into three regions: Europe, the Americas, and Asia (Hitt, Hoskisson, \& Kim, 1997). There were no firms from Africa, the fourth region in this typology.

\section{Analysis technique and procedure}

Considering the nested nature of my dataset (firms could experience a maximum of two successions during the period of time under study) and the continuous nature of the dependent variables, I estimated a multilevel regression model correcting for the lack of independence of the observations. This model allows me to take into account withinfirm correlations. Furthermore, the database is an unbalanced panel as the number of succession varies by firms (as noted earlier).

\section{RESULTS}

Table 5 below presents the correlation matrix and descriptive statistics. Analyzing the correlation between the predictors, I note that two correlation coefficients are greater than 0.30 (in absolute value); namely, the correlation between the multinational dummy and industry globalization and the association between previous number of cross-border M\&As and log of assets. Hence, I examined potential threat of multicollinearity using variance inflation factors (VIFs). The mean VIF is 1.44 and no individual VIF is higher 
than 2.13 (Kleinbaum, Kupper, \& Muller, 1988). These results indicate that there are no collinearity issues in the model. 
Table 5: Summary Statistics and Zero-Order Correlation Coefficients

\begin{tabular}{|c|c|c|c|c|c|c|c|c|c|c|c|c|c|c|c|c|}
\hline Variables & Mean & SD & 1 & 2 & 3 & 4 & 5 & 6 & 7 & 8 & 9 & 10 & 11 & 12 & 13 & 14 \\
\hline $\begin{array}{l}\text { 1. Change in } \\
\text { cross-border } \\
\text { M\&As }\end{array}$ & 1.97 & 2.87 & 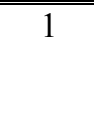 & & & & & & & & & & & & & \\
\hline $\begin{array}{l}\text { 2. Change in } \\
\text { domestic } \\
\text { M\&As }\end{array}$ & 1.66 & 2.66 & 0.12 & 1 & & & & & & & & & & & & \\
\hline $\begin{array}{l}\text { 3. Foreign } \\
\text { succession }\end{array}$ & 0.23 & 0.42 & 0.13 & -0.10 & 1 & & & & & & & & & & & \\
\hline $\begin{array}{l}\text { 4. New CEO } \\
\text { insiderness }\end{array}$ & -0.02 & 13.14 & -0.02 & 0.03 & -0.26 & 1 & & & & & & & & & & \\
\hline $\begin{array}{l}\text { 5. Industry } \\
\text { concentration }\end{array}$ & 0.24 & 0.09 & 0.24 & 0.06 & 0.04 & -0.12 & 1 & & & & & & & & & \\
\hline $\begin{array}{l}\text { 6. Industry } \\
\text { globalization }\end{array}$ & 0.42 & 0.18 & 0.11 & -0.08 & 0.17 & -0.01 & -0.03 & 1 & & & & & & & & \\
\hline 7. Firm age & 97.31 & 77 & 0.04 & -0.11 & 0.08 & -0.07 & -0.12 & 0.16 & 1 & & & & & & & \\
\hline $\begin{array}{l}\text { 8. Adjusted } \\
\text { ROA }\end{array}$ & -0.74 & 6.26 & -0.04 & 0.05 & 0.06 & -0.01 & -0.02 & 0.01 & 0.01 & 1 & & & & & & \\
\hline 9. Log of assets & 10.82 & 1.53 & 0.31 & 0.14 & -0.02 & -0.06 & 0.04 & 0.10 & 0.19 & 0.01 & 1 & & & & & \\
\hline $\begin{array}{l}\text { 10. Free cash } \\
\text { flow }\end{array}$ & $\begin{array}{c}2247 . \\
59\end{array}$ & $\begin{array}{c}12848 . \\
79\end{array}$ & 0.02 & -0.01 & 0.09 & -0.03 & 0.08 & 0.00 & -0.01 & 0.00 & 0.08 & 1 & & & & \\
\hline $\begin{array}{l}11 . \\
\text { Multinational } \\
\text { dummy }\end{array}$ & 0.83 & 0.37 & 0.19 & 0.00 & 0.16 & -0.18 & -0.01 & 0.40 & 0.07 & -0.03 & 0.20 & 0.01 & 1 & & & \\
\hline $\begin{array}{l}\text { 12. CEO's Intl. } \\
\text { Experience }\end{array}$ & 4.33 & 6.91 & 0.04 & -0.09 & 0.26 & -0.31 & 0.08 & 0.18 & 0.10 & 0.00 & 0.03 & 0.04 & 0.14 & 1 & & \\
\hline $\begin{array}{l}\text { 13. Number of } \\
\text { cross-border } \\
\text { M\&As (pre- } \\
\text { succession) }\end{array}$ & 3.56 & 6.04 & 0.58 & 0.13 & 0.08 & -0.13 & 0.08 & 0.09 & 0.16 & -0.00 & 0.42 & -0.24 & 0.22 & 0.13 & 1 & \\
\hline $\begin{array}{l}\text { 14. Number of } \\
\text { domestic } \\
\text { M\&As (pre- } \\
\text { succession) }\end{array}$ & 2.26 & 3.33 & 0.17 & 0.56 & -0.09 & 0.15 & 0.10 & -0.03 & -0.06 & 0.11 & 0.25 & -0.10 & 0.02 & -0.09 & 0.32 & 1 \\
\hline
\end{tabular}


The results for testing the effect of foreign-born CEOs on change in cross-border M\&As are presented in Table $6(\mathrm{H} 1$ and $\mathrm{H} 3)$. Table 7 provides the results to assess the influence of national CEOs on change in domestic M\&As (H2 and H4). In each model, Model 1 represents the base model introducing only the control variables.

Table 6: Drivers of Changes in Cross-Border M\&As

\begin{tabular}{|c|c|c|c|}
\hline Variables & "Model 1 & "Model 2 & Model 3 \\
\hline \multicolumn{4}{|l|}{ Control variables } \\
\hline Firms' region of origin & n.s. & n.s. & n.s. \\
\hline Year of hire & $-0.06^{\dagger}$ & $-0.07^{*}$ & -0.03 \\
\hline Industry concentration & $-0.91^{\dagger}$ & $-0.88^{\dagger}$ & -0.43 \\
\hline Industry globalization & 0.27 & 0.26 & 0.16 \\
\hline Firm age & $-0.00^{\dagger}$ & $-0.00^{\dagger}$ & $-0.00^{\dagger}$ \\
\hline Adjusted ROA & -0.00 & -0.00 & -0.00 \\
\hline Log of assets & 0.04 & 0.04 & 0.02 \\
\hline Free cash flow & $0.00^{* * *}$ & & $0.00^{* * *}$ \\
\hline & & $0.00^{* * *}$ & \\
\hline Multinational dummy & 0.05 & 0.04 & 0.04 \\
\hline CEO's intl. experience & 0.00 & -0.00 & -0.00 \\
\hline $\begin{array}{l}\text { Previous number of cross-border } \\
\text { M\&As (pre-succession) }\end{array}$ & $0.10^{* * *}$ & $0.10^{* * *}$ & $0.10^{* * * *}$ \\
\hline \multicolumn{4}{|l|}{ Predictor variables } \\
\hline Foreign succession $(\mathrm{H} 1)$ & & $0.31 *$ & $1.08 * * *$ \\
\hline New CEO insiderness & & & .002 \\
\hline $\begin{array}{l}\text { Foreign succession X New CEO } \\
\text { insiderness }(\mathrm{H} 2)\end{array}$ & & & $0.126^{* * *}$ \\
\hline $\mathrm{N}$ & 261 & 261 & 261 \\
\hline Wald chi-square & $169.46^{* * *}$ & $175.92 * * *$ & $251.95 * * *$ \\
\hline Log restricted-likelihood & -345.99 & -344.77 & -331.36 \\
\hline
\end{tabular}


Table 7: Drivers of Changes in Domestic M\&As

\begin{tabular}{|c|c|c|c|}
\hline Variables & Model 1 & Model 2 & Model 3 \\
\hline \multicolumn{4}{|l|}{ Control variables } \\
\hline Firms' region of origin & n.s. & n.s. & n.s \\
\hline Year of hire & -0.00 & -0.00 & -0.04 \\
\hline Industry concentration & -0.03 & -0.04 & 0.34 \\
\hline Industry globalization & -0.20 & -0.20 & -0.33 \\
\hline Firm age & -0.00 & -0.00 & $-0.00 *$ \\
\hline Adjusted ROA & -0.00 & -0.00 & 0.01 \\
\hline Log of assets & 0.00 & 0.00 & $0.09 *$ \\
\hline Free cash flow & 3.44 & 3.66 & 8.82 \\
\hline Multinational dummy & 0.01 & 0.01 & 0.05 \\
\hline CEO's intl. experience & -0.00 & 0.00 & -0.00 \\
\hline $\begin{array}{l}\text { Previous number of domestic M\&As } \\
\text { (pre-succession) }\end{array}$ & $0.17^{* * *}$ & $0.17^{* *}$ & 0.01 \\
\hline \multicolumn{4}{|l|}{ Predictor variables } \\
\hline National succession (H2) & & -0.11 & -0.12 \\
\hline New CEO insiderness & & & -6.06 \\
\hline $\begin{array}{l}\text { National succession * New CEO } \\
\text { insiderness }(\mathrm{H} 4)\end{array}$ & & & -0.00 \\
\hline $\mathrm{N}$ & 261 & 261 & 261 \\
\hline Wald chi-square & $122.83^{* * *}$ & $123.00^{* * *}$ & 19.69 \\
\hline Log restricted-likelihood & -361.53 & -362.13 & -409.85 \\
\hline
\end{tabular}

Starting with the analysis of table 2 (testing $\mathrm{H} 1$ and $\mathrm{H} 3$ ), in model 1 the coefficients for firm age, industry concentration, free cash flow, and previous number of cross-border M\&As are statistically significant.

Model 2 tests the results for $\mathrm{H} 1$ in which the link between foreign-born CEOs and changes in international M\&As is hypothesized. As shown in model 2, foreign-born succession is statistically significant $(\mathrm{p}<0.05)$ and the sign of the coefficient is positive. These results provide support for H1. Model 3 tests the interaction of foreign-born successions and new CEOs' insiderness (H3). The coefficient for the interaction term is positive and statistically significant $(\mathrm{p}<0.001)$ lending support for $\mathrm{H} 3$. This result 
indicates that the positive effect of foreign succession on changes in cross-border M\&As is stronger at higher levels of insiderness.

Table 3 examines the impact of national CEOs on changes in domestic M\&As (H2). Model 1 suggests that there is positive relationship between changes in domestic M\&As and previous number of domestic M\&As $(\mathrm{p}<0.001)$. This result remains stable in model 2 .

As shown in model 2, the relationship between national successions and changes in domestic M\&As (H2) is not supported (always the sign of the coefficient is negative as predicted). Model 3 tests the interaction of national successions and new CEOs' insiderness (H4). The coefficient for the interaction term is not statistically significant. Hence, H4 is not supported.

\section{Post hoc analysis and robustness checks}

I conducted an additional series of test to check the robustness and stability of the findings. First, I used alternative operationalizations of some covariates. I reran the models using two alternative measures of performance: adjusted return on equity and sales growth. The results remain almost unchanged except that the significance level for the foreign succession coefficient (testing $\mathrm{H} 1$ ) became marginal when using sales growth $(\mathrm{p}=0.07)$. Likewise, I obtained identical results when employing different measures of firm size including log of sales and log of employees. In addition, I retested the hypotheses using firms' degree of internationalization as opposed to the Multinational dummy used in the models reported in table 2 . The findings were consistent with the ones reported in the results section. 
Second, I introduced other controls. Succession research has highlighted the influence of the similarity between a new $\mathrm{CEO}$ and his/her predecessor on strategic change (Finkelstein et al., 2009). I therefore added to the statistical analysis a dummy variable controlling for the previous CEO's national origin. Previous CEO's national origin is a dummy variable taking a value of 1 if the previous CEO was born and raised in a country other than his/her firm's headquarter country and 0 otherwise. I identified previous CEOs' name using Bloomberg, directory of corporate affiliations, and company's annual reports and 20F. To identify their national origin, I used the same sources as the ones employed to find the national origin of newly appointed CEOs. The results were consistent with the ones described above. I also controlled for $C E O$ age since previous research has shown that younger CEOs might have a tendency to engage in more risky types of strategic initiatives vis-à-vis their older counterparts (Hambrick \& Mason, 1984). The results were also in line with my earlier findings.

Finally, I retested the hypotheses using OLS and applying a correction for intragroup correlation (given that one company could experience two successions during the time period under study). The results were consistent with the ones reported above. I would like to nevertheless note the significance level for the foreign succession coefficient (testing H1) improved slightly $(\mathrm{p}=0.016)$ compared to the $\mathrm{p}$-value obtained when testing the model reported in table $2(\mathrm{p}=0.039)$.

\section{DISCUSSION AND CONCLUSION}

CEO succession is a unique and visible event, with a likely critical impact on

firms' external and internal stakeholders (e.g., Zhang \& Rajagopalan, 2004). During the 
past decades, researchers have paid considerable attention to CEO origin and its link to firm strategy, ignoring CEOs' country of origin (see Kesner \& Sebora, 1994 and Giambatista et al., 2005 for a review). In this research, I extend this body of work by demonstrating the salience of CEOs' country of origin, a type of successor origin that has not been examined in the current CEO succession literature.

More specifically, examining firms' expansion via mergers and acquisitions, I demonstrate that foreign successions significantly differ from national successions. I find that foreign successors are likely to engage in more changes related to cross-border mergers and acquisitions than their national counterparts. This link could be explained by the fact that foreign CEOs are likely to have an imprinting and mindset that may be less embedded in firms' home country vis-à-vis their national counterparts. Also, boards of directors may expect foreign CEOs to extend the realm of companies to the global arena prompting them to consider international expansion in a more salient way than domestic expansions $(F T, 2012)$. This result complements the findings of prior studies exploring the link between CEO origin and different outcomes such as strategic resource allocations (e.g., Wiersema, 1992), corporate strategic refocusing (e.g., Bigley \& Wiersema, 2002), or firm performance (e.g., Karaevli, 2007; Shen \& Canella, 2002).

Focusing on chief executives, this study also contributes to the burgeoning literature on executives' national origin. In a conceptual paper published in 1998, Hambrick and colleagues highlighted that there are considerable traces of nationality in people's behaviors. Using a sample of global 500 companies, the present study indicates that such traces of nationality could be manifested in the context of M\&A strategy. In addition, most of the research addressing the impact of nationality has been confined to 
the group setting. For example, Ahmadjian and Robins (2005) studied the influence of foreign investors on Japanese companies and showed that the presence of foreign investors fostered the adoption of shareholder-based governance. Ramaswamy and $\mathrm{Li}$ (2001) surveyed the influence of foreign board members on the corporate diversification of Indian firms. Nielsen and Nielsen (2013) demonstrated the positive influence of TMT national diversity on firm performance in the context of Swiss companies. We may also note that these studies are conducted within the realm of one national setting or country. This study broadens this endeavor by looking at a global sample of firms, the Global 500 .

Finally, addressing the interplay between CEOs' country of origin and their degree of insiderness offers important implications for CEO succession research. As noted earlier, recent research has brought to the fore the need to consider multiple facets of successor origin (Karaevli, 2007; Zhang \& Rajagopalan, 2003; 2004). While previous research has largely theorized on the drawbacks of outsiderness and insiderness, this study explores some of the obstacles associated with "foreignness" which could be mitigated by CEOs' prior experience with the organization.

As a first attempt to study the strategic consequences of foreign-born successions, this study has some limitations offering some promising avenues for future research. First, this study's scope is confined to changes in mergers and acquisitions without taking into account organic growth or other entry modes (Barkema \& Vermeulen, 1998). Future research could consider strategic expansion via different entry modes. Second, the data used in this research contain only mergers and acquisitions that have reached the stage of public announcements. While SDC Platinum uses data collected from SEC filings and filings made to similar regulatory bodies in foreign countries and from a number of other 
outlets (e.g., news, trade publications) and offers a very comprehensive database, there may be some transactions that may not be captured by the data (Dikova et al., 2009). Third, the use of large global 500 firms could limit the generalizability of the findings. Future research could focus on other related questions related to foreign-born CEO successions. An extension of this study could be the examination of patterns of geographical expansions. For example, do foreign-born CEOs initiate more expansions in their region of origin vis-à-vis other regions? One could argue that country (region)specific skills could help them pursue expansion opportunities in their region of origin. Second, while we know that CEOs are likely to influence firm strategy, extant research has also identified the implications of successions for firm success. Future research could investigate the performance implications of foreign-born successions and the strategic changes which they may impart.

In summary, this study is the first according to my knowledge to survey the strategic implications of hiring a foreign-born individual to head the corporate suite. I hope it prompts management theorists to delve further into the strategic implications of foreign-born CEO successions. 


\section{REFERENCES}

ABC News. (2009). Trujillo's parting shot at 'racist, backward' Australia. May 26.

Aiken, L. S., \& West, S. G. 1991. Multiple regression: Testing and interpreting interactions. Newbury Park, CA: Sage.

Ahmadjian, C. L., \& Robbins, G. E. (2005). A clash of capitalisms: Foreign shareholders and corporate restructuring in 1990s Japan. American Sociological Review, 70(3), 451471.

Barkema, H. G., \& Mannix, E. A. (2002). Management challenges in a new time. The Academy of Management Journal, 45(5), 916-930.

Barkema, H. G., \& Vermeulen, F. (1998). International expansion through start-up or acquisition: A learning perspective. Academy of Management Journal, 41(1), 7-26.

Bartlett, C., \& Ghoshal, S. (1989). Managing across borders: The transnational solution. Harvard Business School Press.

Benet-Martínez, V., Leu, J., Lee, F., \& Morris, M. W. (2002). Negotiating biculturalism cultural frame switching in biculturals with oppositIonal versus compatible cultural identities. Journal of Cross-Cultural Psychology, 33(5), 492-516.

Bergh, D. D., \& Fairbank, J. F. (2002). Measuring and testing change in strategic management research. Strategic Management Journal, 23(4), 359-366.

Bigley, G. A., \& Wiersema, M. F. (2002). New CEOs and corporate strategic refocusing: How experience as heir apparent influences the use of power. Administrative Science Quarterly, 47(4), 707-727.

Boeker, W. (1997). Executive migration and strategic change: The effect of top manager movement on product-market entry. Administrative Science Quarterly, 42(2), 213-236.

Cannella, A. A., \& Lubatkin, M. (1993). Succession as a sociopolitical process: Internal impediments to outsider selection. Academy of Management Journal, 36(4), 763-793.

Capron, L., Dussauge, P., \& Mitchell, W. (1998). Resource redeployment following horizontal acquisitions in Europe and North America, 1988-1992. Strategic Management Journal, 19(7), 631-661.

Carpenter, M. A., Sanders, W. G., \& Gregersen, H. B. (2001). Bundling human capital with organizational context: The impact of international assignment experience on multinational firm performance and CEO pay. Academy of Management Journal, 44(3), 493-511. 
Carlson, R. O. (1961). Succession and performance among school superintendents. Administrative Science Quarterly, 6(2), 210-227.

Carpenter, M. A., \& Fredrickson, J. W. (2001). Top management teams, global strategic posture, and the moderating role of uncertainty. Academy of Management Journal, 44(3), 533-545.

Chacar, A. S., \& Hesterly, W. (2008). Institutional settings and rent appropriation by knowledge-based employees: The case of major league baseball. Managerial and Decision Economics, 29(23), 117-136.

Chacar, A. S., Newburry, W., \& Vissa, B. (2010). Bringing institutions into performance persistence research: Exploring the impact of product, financial, and labor market institutions. Journal of International Business Studies, 41(7), 1119-1140.

Chen, G., \& Hambrick, D. C. (2012). CEO replacement in turnaround situations: Executive (mis) fit and its performance implications. Organization Science, 23(1), 225 243.

Child, J. (1972). Organizational structure, environment and performance: The role of strategic choice. Sociology, 6(1), 1-22.

Chung, C., \& Luo, X. R. (2013). Leadership succession and firm performance in an emerging economy: Successor origin, relational embeddedness, and legitimacy. Strategic Management Journal, 34(3), 338-357.

Daily, C. M., Certo, S. T., \& Dalton, D. R. (2000). International experience in the executive suite: The path to prosperity? Strategic Management Journal, 21(4), 515-523.

Dikova, D., Sahib, P. R., \& van Witteloostuijn, A. (2009). Cross-border acquisition abandonment and completion: The effect of institutional differences and organizational learning in the international business service industry, 1981-2001. Journal of International Business Studies, 41(2), 223-245.

Duvander, A. E. (2001). Do country-specific skills lead to improved labor market positions? An analysis of unemployment and labor market returns to education among immigrants in Sweden. Work and Occupations, 28(2), 210-233.

Financial Times. (2012). Foreign CEOs face challenges in Japan. April 29.

Finkelstein, S., Hambrick, D. C., \& Cannella, A. A. (2009). Strategic leadership: Theory and research on executives, top management teams, and boards Oxford University Press, USA. 
Fiske, S. T., \& Taylor, S. E. (1984). Social cognition. Reading, MA: Addison-Wesley.

Forbes. (2009). Eight Indian CEOs At Big U.S. Companies. December 21.

Gabarro, J. J. (1987). The dynamics of taking charge. Boston: Harvard Business School Press.

Geletkanycz, M. A. (1997). The salience of 'culture's consequences': The effects of cultural values on top executive commitment to the status quo. Strategic Management Journal, 18(8), 615-634.

Giambatista, R. C., Rowe, W. G., \& Riaz, S. (2005). Nothing succeeds like succession: A critical review of leader succession literature since 1994. The Leadership Quarterly, 16(6), 963-991.

Groysberg, B., McLean, A. N., \& Nohria, N. (2006). Are leaders portable? Harvard Business Review, 84(5), 92.

Grusky, O. (1961). Corporate size, bureaucratization, and managerial succession. American Journal of Sociology, 67(3), 261-269.

Hambrick, D. C., \& Mason, P.A. (1984). Upper echelons: the organization as a reflection of its top managers. Academy of Management Review, 9(2), 193-206.

Hambrick, D. C., Davison, S. C., Snell, S. A., \& Snow, C. C. (1998). When groups consist of multiple nationalities: Towards a new understanding of the implications. Organization Studies, 19(2), 181-205.

Harford, J. (1999). Corporate cash reserves and acquisitions. The Journal of Finance, 54(6), 1969-1997.

Harris, D., \& Helfat, C. (1997). Specificity of CEO human capital and compensation. Strategic Management Journal, 18(11), 895-920.

Helfat, C. E., \& Bailey, E. E. (2005). External succession and disruptive change: Heirsapparent, forced turnover and firm performance. Strategic Organization, 3(1), 47-83.

Helmich, D. L. (1974). Organizational growth and succession patterns. Academy of Management Journal, 17(4), 771-775.

Hitt, M. A., Hoskisson, R. E., \& Kim, H. (1997). International diversification: Effects on innovation and firm performance in product-diversified firms. Academy of Management Journal, 40(4), 767-798. 
Karaevli, A. (2007). Performance consequences of new CEO 'Outsiderness': Moderating effects of pre and post-succession contexts. Strategic Management Journal, 28(7), 681706.

Kesner, I. F., \& Sebora, T. C. (1994). Executive succession: past, present \& future. Journal of Management, 20(2), 327-372.

Kleinbaum, D.G., Kupper, L.L., \& Muller, K.E. (1988). Applied Regression Analysis and Other Multivariable Methods. PWS Publishing: Boston, MA.

Lewis, B. W., Walls, J. L., \& Dowell, G. W. (2013). Difference in degrees: CEO characteristics and firm environmental disclosure. In print. Strategic Management Journal.

Luo, X., Kanuri, V. K., \& Andrews, M. (2013). How does ceo tenure matter? The mediating role of firm-employee and firm-customer relationships. Strategic Management Journal.

Miller, D. (1991). Stale in the saddle: CEO tenure and the match between organization and environment. Management Science, 37(1), 34-52.

Miller, D. (1993). Some organizational consequences of CEO succession. Academy of Management Journal, 36(3), 644-659.

Nadkarni, S., \& Perez, P. D. (2007). Prior conditions and early international commitment: The mediating role of domestic mindset. Journal of International Business Studies, 38(1), 160-176.

New York Times. (2005). An Inside Job. March 27.

New York Times. (2007). Foreign-born chiefs reflect Fortune 100's global reach. December 12.

Nielsen, B. B., \& Nielsen, S. (2013). Top management team nationality diversity and firm performance: A multilevel study. Strategic Management Journal, 34(3), 373-382.

Ocasio, W. (1999). Institutionalized action and corporate governance: The reliance on rules of CEO succession. Administrative Science Quarterly, 44(2), 384-416.

Quigley, T. J., \& Hambrick, D. C. (2012). When the former ceo stays on as board chair: effects on successor discretion, strategic change, and performance. Strategic Management Journal, 33(7), 834-859. 
Ramaswamy, K., \& Li, M. (2001). Foreign investors, foreign directors and corporate diversification: An empirical examination of large manufacturing companies in India. Asia Pacific Journal of Management, 18(2), 207.

Shen, W., \& Cannella, A. A. (2002). Revisiting the performance consequences of CEO succession: The impacts of successor type, postsuccession senior executive turnover, and departing CEO tenure. Academy of Management Journal, 45(4), 717-733.

Spender, J. C. (1989). Industry recipes: The nature and sources of managerial judgment: Cambridge: MA, Basil Blackwell Ltd.

Takeuchi, R., Tesluk, P. E., Yun, S., \& Lepak, D. P. (2005). An integrative view of international experience. Academy of Management Journal, 48(1), 85-100.

The Economist. (2012). The wheel of fortune. March 26.

The Huffington Post. (2012). Michael Woodford, Ex-Olympus CEO, Wins Multi-Million Dollar Settlement. May 29.

Tushman, M. L., Virany, B., \& Romanelli, E. (1985). Executive succession, strategic reorientations, and organization evolution: The minicomputer industry as a case in point. Technology in Society, 7(2), 297-313.

Vancil, R. F. (1987). Passing the baton: Managing the process of CEO succession. Harvard Business School Press: Boston, MA.

Wall Street Journal. (2004). Foreign-Born CEOs Are Increasing in U.S., Rarer Overseas. May 25.

Westphal, J. D., \& Deephouse, D. L. (2011). Avoiding bad press: Interpersonal influence in relations between CEOs and journalists and the consequences for press reporting about firms and their leadership. Organization Science, 22(4), 1061-1086.

Wiersema, M. F. (1992). Strategic consequences of executive succession within diversified firms. Journal of Management Studies, 29(1), 73-94.

Wiersema, M. F. (1995). Executive succession as an antecedent to corporate restructuring. Human Resource Management, 34(1), 185-202.

Wiersema, M. F., \& Bantel, K. A. (1992). Top management team demography and corporate strategic change. Academy of Management Journal, 35(1), 91-121.

Zhang, Y., \& Rajagopalan, N. (2003). Explaining new CEO origin: Firm versus industry antecedents. Academy of Management Journal, 46(3), 327-338. 
Zhang, Y., \& Rajagopalan, N. (2004). When the known devil is better than an unknown god: An empirical study of the antecedents and consequences of relay CEO successions. Academy of Management Journal, 47(4), 483-500.

Zhang, Y., \& Rajagopalan, N. (2010a). Once an outsider, always an outsider? CEO origin, strategic change, and firm performance. Strategic Management Journal, 31(3), 334-346.

Zhang, Y., \& Rajagopalan, N. (2010b). CEO succession planning: Finally at the center stage of the boardroom. Business Horizons, 53(5), 455. 
VITA

YANNICK THAMS

\title{
EDUCATION
}

\author{
Master in International Business \\ 2004 \\ Florida International University
}

\section{PhD in Management and International Business}

2013

Florida International University

Dissertation Chair: Aya Chacar

Committee Members: Joyce Elam, William Newburry, Mary Ann Von Glinow, Margarethe Wiersema

G.P.A.: $3.96 / 4$

\section{WORK EXPERIENCE}

Part-Time Lecturer

2009-Present

Florida International University, Miami (FL)

Full Time Project Manager and Instructional Designer

2005-2008

Executive and Professional Education - College of Business Administration

Florida International University, Miami (FL)

Part-Time Adjunct Professor

2006-2007

Florida International University, Miami (FL)

Courses taught: Business in the Caribbean, International Business

\section{Management Internship}

2003

General Motors, South Carolina

\section{PUBLICATIONS AND PRESENTATIONS}

Thams, Y., Liu, Y., \& Von Glinow, M.A. 2013. Asian favors: more than a cookie cutter approach. Asia Pacific Journal of Management (ranked \#18 among all management journals with an impact factor of 3.36).

Chacar, A.S., Celo, S., \& Thams, Y. 2010. The performance of multinational affiliates versus domestic. Journal of Management Policy and Practice, 11(4): 47-59. 
Thams, Yannick \& Chacar, A.S. 2012. Foreign CEO Appointments in the Multinational Enterprise: Rational Motives and Homophilic Constraints. AIB Conference, Washington DC.

Chacar, A.S., \& Thams, Y. 2012. New CEOs' International Profile and International Strategy. SMS Conference, Prague.

Thams, Y. 2012. Globalization pressures and CEO selection. SMS Conference, Prague.

Thams, Y., Liu, Y., \& Von Glinow, M.A. 2012. Asian favors: more than a cookie cutter approach. AOM Conference, Boston.

Zakaria, R., Thams, Y., \& Kelley, K. 2011. Institutional distance and M\&As activities: a quest for relative importance. AOM Conference, San Antonio.

Thams, Y., Alvarado-Vargas, M., \& Newburry, N. 2011. Multinationality as a predictor of MNCs' intangible performance. AIB Conference, Japan.

Kelley, K., Alvarado, M., Thams, Y., \& Yang, K. 2010. Institutional distance during uncertainty: when foreignness isn't such a liability. SMS Conference, Italy.

Thams, Y., \& Kundu, S. 2010. Institutional distance and the emerging markets multinational. AIB Conference, Brazil.

Thams, Y., Kelley, K., Hiller, N., \& Kroeck, G. 2010. Effect of Macro-Environmental Conditions on the Internationalization of Emerging Market Multinationals: A Managerial Discretion Perspective. AIB Conference, Brazil.

Kelley, K., Alvarado, M., \& Thams, Y. 2009. Regionalization and Economic Growth Volatility: An IB Perspective on Dreher's 2006 Article Linking Globalization Index Levels and Economic Growth. AIB Conference, San Diego.

\section{AWARDS, HONORS, AND GRANTS}

Florida-France Linkage Institute Scholarship (\$1500)

FIU Last Year Dissertation Fellowship $(\$ 16,600)$

Jane D. Cope Scholarship (\$500)

2012-2013

Organization for Women in International Trade Award (\$2000) 